\title{
Ronyelle Vasconcelos-Teixeira
}

Relação entre elementos traço, resposta imune inata e níveis hormonais de anuros da espécie Rhinella diptycha

Relationship among trace elements, innate immune response and hormone levels of anurans Rhinella diptycha

São Paulo 


\section{Ronyelle Vasconcelos-Teixeira}

Relação entre elementos traço, resposta imune inata e níveis hormonais de anuros da espécie Rhinella diptycha

\section{Relationship among trace elements, innate immune response and hormone levels of anurans Rhinella diptycha}

Dissertação apresentada ao Instituto de Biociências da Universidade de São Paulo, para a obtenção do Título de Mestre em Ciências, na Área de Fisiologia Geral.

Orientador: Fernando Ribeiro Gomes Co-Orientadora: Vania Regina Assis 


\section{Ficha Catalográfica}

Vasconcelos-Teixeira, Ronyelle

Relação entre elementos traço, resposta imune inata e níveis hormonais de anuros da espécie Rhinella diptycha. Ronyelle Vasconcelos-Teixeira; orientador Fernando Ribeiro Gomes; coorientadora Vania Regina Assis -- São Paulo, 2020.

$74 \mathrm{f}$.

Dissertação (Mestrado) - Instituto de Biociências da Universidade de São Paulo. Departamento de Fisiologia.

1. Contaminação. 2. Anfíbios. 3. Ecoimunologia. 4. Estresse. 5. Corticosterona. I. Gomes, Fernando Ribeiro. II. Assis, Vania Regina. III. Título.

\section{Comissão Avaliadora}

Prof. Dra. Renata Guimarães Moreira

Prof. Dra. Leticia Veras Costa Lotufo

Prof. Dr. José Eduardo Carvalho

Orientador Prof. Dr. Fernando Ribeiro Gomes 


\section{DEDICATÓRIA}

Às forças do universo, ou como quiserem nomeá-las (os);

Aos meus pais;

A todos os meus mestres. 


\section{EPÍGRAFE}

"Never before have we had such an awareness of what we are doing to the planet, and never before have we had the power to do something about that... The future of humanity and indeed, all life on earth, now depends on us."

\section{- David Attenborough}




\section{AGRADECIMENTOS}

Gostaria de agradecer:

Ao meu orientador, Fernando Ribeiro Gomes, pelo incentivo e apoio em todos os momentos. Pelas palavras calmas e compreensivas sempre que são necessárias. Pelas risadas e pela forma que você vê o mundo, isso torna tudo mais admirável. Você é um ser humano incrivelmente inteligente!

À minha co-orientadora, Vania Regina de Assis, pela ajuda e contribuições importantíssimas tanto no projeto quanto na minha formação profissional. Sem você a vida ainda estaria um caos. E por sempre torcer e acreditar em mim, você não tem ideia do quanto isso foi/é importante para mim.

À minha segunda co-orientadora, Stefanny Christie Monteiro Titon, pelos ensinamentos das técnicas do laboratório. Pela ajuda fundamental na coleta. Pelas conversas e apoio. Pelas ideias e freios necessários. Você foi muito importante no desenvolvimento desse mestrado, você foi, minha mestre!

Aos técnicos Márcio de Patto Lima e Raphaela Cantarino Ribeiro pela ajuda na coleta.

Ao professor, Marcelo Luiz Martins Pompêo, pela ajuda no desenvolvimento do projeto. Pelos ensinamentos e disponibilidade de equipamentos. Pela disponibilidade do laboratório para análises de uma parte das minhas amostras. Sem você, parte essencial desse trabalho não teria sido feita.

Ao professor, Jorge Alberto Soares Tenório, pela ajuda com a disponibilidade de equipamentos, necessários para a análise dos metais.

À técnica do Laboratório de Reciclagem, Tratamento de Resíduos e Extração (LAREX), Ana Carolina Fadel Dalsin, pela ajuda com a padronização da metodologia. Pelos ensinamentos das análises químicas e leituras das amostras.

À Sheila Cardoso da Silva e Rayssa de Lima Cardoso, do Laboratório de Limnologia, pelos ensinamentos e ajuda nas análises dos nutrientes e dos metais.

À Roseli, do departamento de Fisiologia, e a Érica, da secretaria de Pós-graduação, por toda a ajuda com as burocracias da pós.

Ao Braz Titon Junior, pelas conversas, pelas edições de imagens, e principalmente, pela ajuda com a análise estatística. Sem você não saberia nem como fazer uma ANOVA.

Aos companheiros do Laboratório de Comportamento e Biologia Evolutiva (LaCoFiE), Aymam, Carla, Caroline e Diego pelas conversas e momentos de descontração.

À minha família longe de casa: Adriana Giorgi Barsotti (Di), Stefane Saruhashi (Ste), Faride Lamadrid Feris (Fari), Renata Ibelli Vaz (Renatita), Laura Camila Cabanzo Olarte (Cami), Daniela Cristina Wilwert (Dani), Débora Silva (Dé), Bruna de Oliveira Cassettari (Bru), Isabela Rodrigues (Isa) e Jade Lima dos Santos. Muito obrigada pelas conversas, conselhos, distrações e risadas. Vocês foram muito importantes para a minha sanidade nessa loucura que é a vida de uma pós-graduanda. 
Aos meus pais, Alzira Maria de Vasconcelos e Raimundo Divaldo Teixeira, aqueles dois seres humanos incrivelmente gentis e simples. Vocês sempre serão meu porto seguro, mesmo na distância, vocês são aquelas pessoas que sempre deram tudo por mim e para mim. Mesmo quando parecia impossível, vocês faziam aquele esforço tremendo para me ver feliz. Muito obrigada por serem!

Ao meu irmão, Rômulo Vasconcelos Teixeira, muito obrigada pelos ensinamentos.

À minha irmã de pais diferentes, Patrícia Albuquerque da Silva você é uma das mulheres mais incríveis que conheço. Você é uma pessoa que apesar de todas as turbulências do mundo continua de pé e orgulha a todos. Muito obrigada por estar sempre disponível para uma discussão, seja ela existencial ou de trabalho. Muito obrigada por discutir estatística comigo até altas horas da noite, e me ajudar com testes que eu nem sabia que existiam. Você é minha inspiração e exemplo na biologia!

Aos meus roommates, Silvana, Filipe e Daniel, vocês são pessoas incríveis que me acolheram nessa cidade, e transformamos nossa casa em um Lar. 
O presente trabalho contou com o apoio das seguintes instituições:

$\checkmark$ Coordenação de Aperfeiçoamento de Pessoal de Nível Superior (CAPES):

Bolsa de estudo (Aluna).

Suporte financeiro para coletas e compra de materiais.

$\checkmark$ Fundação de Amparo à Pesquisa do Estado de São Paulo (FAPESP):

Projeto Temático (2014/16320-7).

$\checkmark$ Programa de Pós-Graduação em Fisiologia Geral - Departamento de Fisiologia Instituto de Biociências - Universidade de São Paulo - São Paulo.

$\checkmark$ Departamento de Fisiologia - Instituto de Biociências - Universidade de São Paulo - São Paulo.

A coleta foi realizada sob a licença de captura e transporte do Instituto Brasileiro do Meio Ambiente e dos Recursos Naturais Renováveis (IBAMA No $29896-1$ ) e os procedimentos realizados nesse estudo obtiveram autorização prévia do Comitê de Ética no Uso de Animais (CEUA No 303/2017) (Anexo 1). 


\section{ÍNDICE}

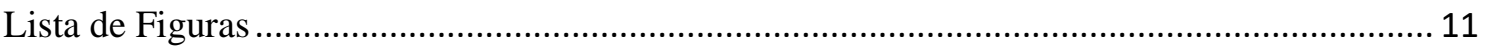

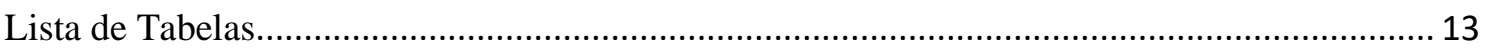

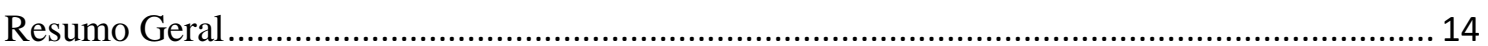

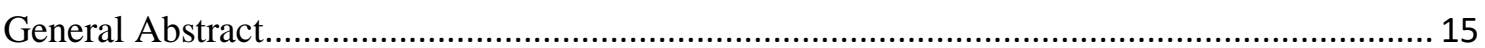

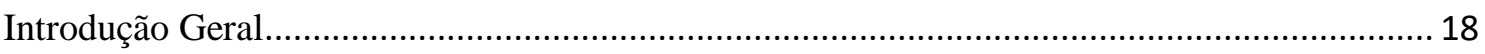

1. Influência dos Metais Pesados na Fauna ...................................................................... 19

2. Glicocorticoides, Estresse e Impacto Ambiental............................................................ 20

3. Anuros como Modelo para Estudar os Efeitos da Contaminação do Ambiente por Metais 22

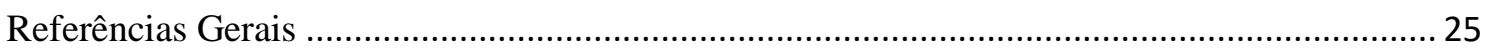

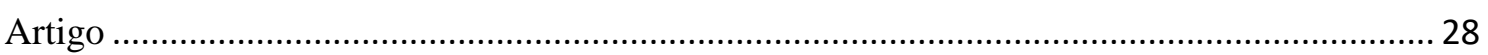

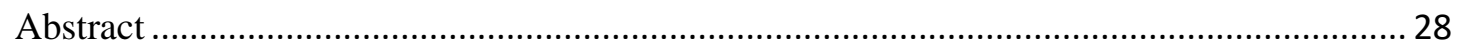

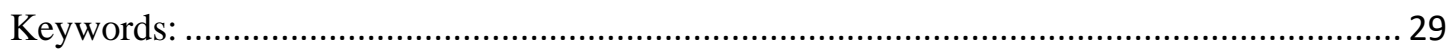

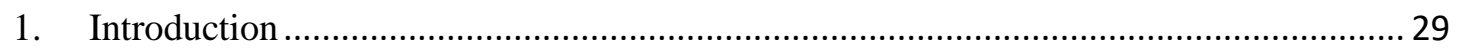

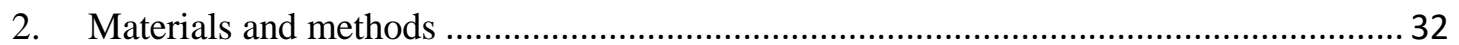

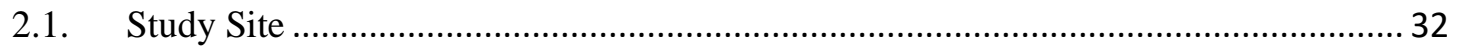

2.2. Water and sediment processing for trace elements quantification ............................. 33

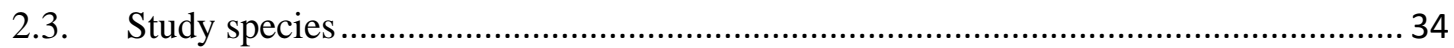

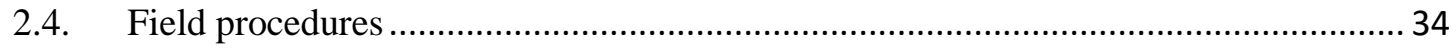

2.5. Tissue sampling and processing for trace elements quantification ............................. 35

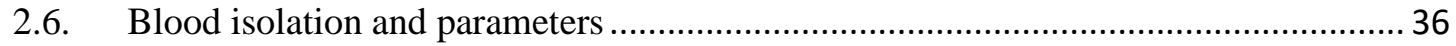

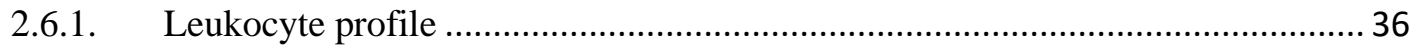

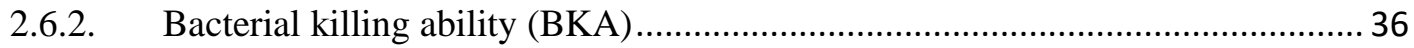

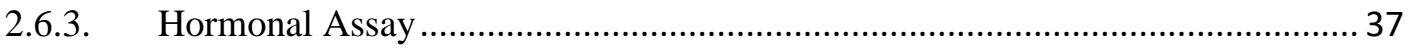

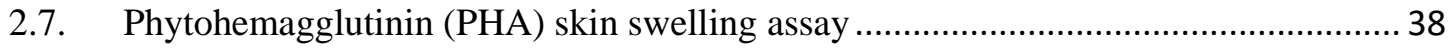

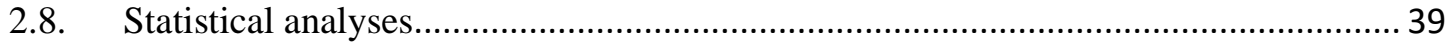

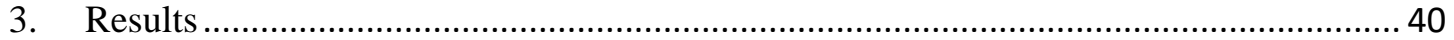

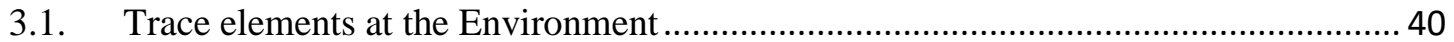

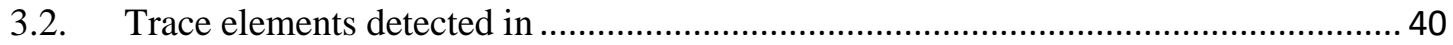

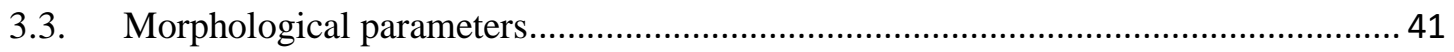

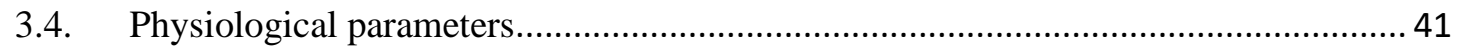

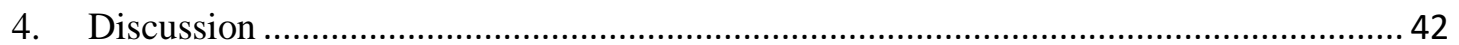

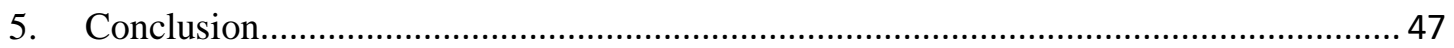




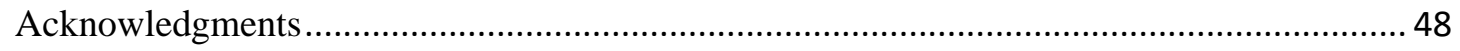

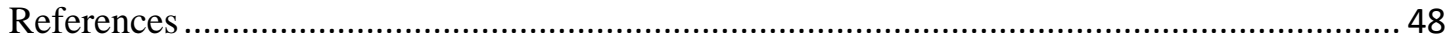

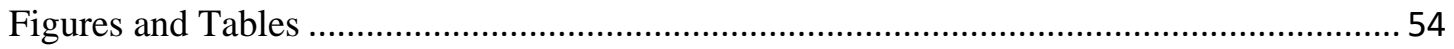

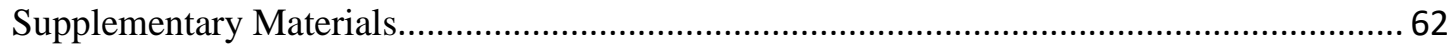

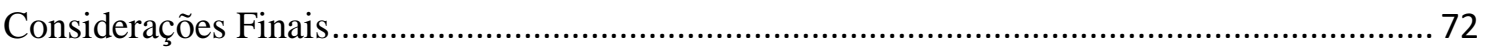

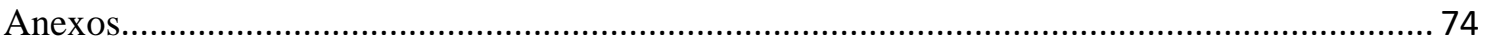




\section{LISTA DE FIGURAS}

Figure 1: Map of the collection sites, with the perspective of where the dam rupture occurred. The first city by the River is Mariana, which was dam busted. Following the Doce River, there is Ipatinga (MG) $194 \mathrm{~km}$ from the dam rupture; Governador Valadares (MG) $287 \mathrm{~km}$; and Linhares (ES) $549 \mathrm{~km}$ from the dam rupture (near the estuary). Source: Modified from Folha de Sao Paulo. The numbers 1,2 and 3 means the animal's collection sites.

Figure 2: Organs relative mass of Rhinella diptycha among three different collection sites. (A) Relative spleen mass; (B) Relative kidney mass. The symbol (\#) represents the statistical difference between the sites by an ANOVA after Bonferroni correction ( $\mathrm{p} \leq$ 0.05). The numbers in parenthesis represent the number of individuals used on the test. The bars represent the means \pm standard error. Collection sites: 1: Governador Valadares (MG) - 29km away from the Doce River; 2: Linhares (ES) - Doce Riverbanks; and 3: Linhares (ES) - 17km away from the Doce River. .54

Figure 3: Hormone plasma levels of Rhinella diptycha among three different collection sites. (A) Corticosterone (CORT) plasma levels. (B) Testosterone (T) plasma levels. Asterisk $(*)$ represents the statistical difference between baseline and post-restraint levels within each specific site by an ANOVA after Bonferroni correction $(\mathrm{p} \leq 0.05)$. The symbol (\#) represents the statistical difference between the sites by an ANOVA after Bonferroni correction $(\mathrm{p} \leq 0.05)$. The numbers in parenthesis represent the number of individuals used on the test. The bars represent the means \pm standard error. Collection sites: 1: Governador Valadares (MG) - 29km away from the Doce River; 2: Linhares (ES) - Doce Riverbanks; and 3: Linhares (ES) - 17km away from the Doce River....

Figure 4: Immunological parameters in Rhinella diptycha among three different collection sites. (A) Neutrophil: lymphocyte ratio (N:L). (B) Bacterial killing capacity (BKA). (C) Relative edema [calculated by the measurements post-injection minus the measurement before injection times 100 (12-0 or 18-0*100)] of the animals' paw after a PHA injection. (D) Maximum edema of the animals' paw after a PHA injection. Asterisk $(*)$ represents the statistical difference between baseline and post-restraint levels within each specific site by an ANOVA after Bonferroni correction $(\mathrm{p} \leq 0.05)$. The symbol (\#) represents the statistical difference between time post-injection within each specific site by an ANOVA after Bonferroni correction $(\mathrm{p} \leq 0.05)$. The letters $a$ and $b$ represent the statistical difference of maximum swelling among three different sites by an ANOVA after Bonferroni correction $(\mathrm{p} \leq 0.05)$. The numbers in parenthesis represent the number of individuals used on the test. The bars represent the means \pm standard error. Collection sites: 1: Governador Valadares (MG) - 29km away from the Doce River; 2: Linhares (ES) - Doce Riverbanks; and 3: Linhares (ES) - 17km away from the Doce River.................................................................... 56

Figure S1: Binding displacement curves of serially diluted Rhinella diptycha plasma against the standards used in the enzyme immunoassays of corticosterone, testosterone, and estradiol. The y-axis shows the \% hormone bound/total binding measured at $412 \mathrm{~nm}$. 
Fifty percent binding point is denoted using a black dashed line, which determined the best dilution factors for the extracted plasma samples. Displacement curve of pooled plasma collected in the field (A) and $1 \mathrm{~h}$ after restraint (B) against corticosterone standard. Displacement curve of pooled plasma collected in the field (C) and $1 \mathrm{~h}$ after restraint (D) against testosterone standard. Displacement curve of pooled plasma collected in the field (E) and $1 \mathrm{~h}$ after restraint (F) against estradiol standard. The asterisk (*) represents the best dilution factors found for each hormone under each specific situation

Figure S2: Linear Discriminant Analyses (LDA) for multiple groups with the trace elements detected at the liver of Rhinella diptycha. Function 1 discriminate $93.4 \%$ of the data (grouping $\mathrm{Ca}$ ) and Function 2 discriminate $6.6 \%$ of the data (inversely grouping $\mathrm{Zn}$ with $\mathrm{Cu}, \mathrm{Fe}$ and $\mathrm{Mg}$ ). The yellow squares are the samples of site 1 (Governador Valadares (MG): $29 \mathrm{~km}$ away from the Doce River); the red circles represent the samples of site 2 (Linhares (ES): Doce River banks); and the blue triangles are the samples of site 3 (Linhares (ES): 17km away from the Doce River). The black circles are the centroids, which represents the mean of discriminant functions in each group. .64 


\section{LiSTA DE TABELAS}

Table 1: Trace elements concentration in water and sediment

Table 2: Comparison of morphological, trace elements bioaccumulation and physiological parameters among the three collection sites

Table 3: Comparison of physiological, morphological and trace elements bioaccumulation among the three collection sites.

Table S1: Descriptive table of the morphological variables and trace elements in the liver of Rhinella diptycha individuals.

Table S2: Standard canonical discriminant function coefficients for trace elements in Rhinella diptycha livers and their structure matrix .66

Table S3: Group membership classification results (discriminant analysis) of Rhinella diptycha in the three collection sites.

Table S4: Components extracted of a Principal component analysis (PCA) with trace elements presented at Rhinella diptycha livers

Table S5: Descriptive table of hormonal variables of Rhinella diptycha individuals...

Table S6: Descriptive table of immunological variables of Rhinella diptycha individuals................................................................... 70 


\section{RESUMO GERAL}

O estado de Minas Gerais é bastante conhecido por ser um grande polo de mineração, principalmente no chamado quadrilátero ferrífero. Em novembro de 2017, houve o rompimento da barragem de Fundão (mineração de ferro), em Mariana - MG, causando um dos maiores desastres ambientais do país, com a contaminação do Rio Doce. Os anfíbios, como indica sua etimologia, estão intimamente associados aos habitats aquáticos e terrestres, o que os torna vulneráveis a quase todos os tipos de modificação de habitats. Entre essas modificações, as causadas pelo ser humano como fragmentação, introdução de doenças emergentes e espécies invasoras, e poluição, podem ser destacadas como as mais preocupantes. A poluição por elementos traço, por exemplo, pode causar impacto na resposta imune dos anfíbios, dependendo da quantidade e duração da exposição. Isto porque a exposição prolongada a elementos traço pode causar alterações fisiológicas e morfológicas nos animais, incluindo diminuição da resposta imune e aumento dos níveis de mediadores de estresse nos indivíduos, condições normalmente encontradas em quadros de estresse crônico. Sendo assim, nosso objetivo foi avaliar como elementos traços presentes no Rio Doce afetaria diversas variáveis fenotípicas de anuros vivendo ao longo da bacia do Rio Doce. Nossa hipótese era a de que anuros expostos a concentrações de elementos traço presentes no Rio Doce estariam sob estresse crônico, associado à redução das funções reprodutivas e imunológicas e da intensidade da resposta a um estressor agudo secundário. Para testar esta hipótese, analisamos a resposta imune inata e a concentração plasmática de hormônios (corticosterona, testosterona e estradiol), nas situações basal (de campo) e pós-estresse (restrição de 1 h) de sapos Rhinella diptycha, ao longo do Rio Doce. Amostras de sangue foram coletadas antes e após a restrição, seguidas de um desafio imunológico com o mitógeno fitohemaglutinina (PHA) e a coleta de tecidos (fígado, baço e rins). Os locais de coleta foram subdivididos em 3 áreas, de acordo com a quantificação do metal na água e no sedimento: mais contaminado (local 2), intermediário (local 1) e menos contaminado (local 3). De forma geral, houve um aumento nos níveis plasmáticos de corticosterona e uma redução na capacidade bactericida plasmática de todos os animais em todas as áreas após a restrição. Além disso, os sapos do local 3 (menos contaminado) apresentaram maior edema após o desafio com PHA e uma maior relação Neutrófilo: Linfócito pós-restrição. Nossos resultados indicam que, sapos vivendo em ambientes contaminados por elementos traço, foram capazes de responder a um estressor agudo e a um desafio imunológico, entretanto a resposta foi 
mais eficaz nos animais vivendo em ambientes com menor grau de contaminação. Com isso, mostramos que conforme a contaminação ambiental por elementos traço aumenta, menos intensa é a resposta de defesa imunitária de sapos que vivem nestes ambientes, o que poderia comprometer seu valor adaptativo.

Palavras chave: Contaminação; Anfíbios; Ecoimunologia; Estresse; Corticosterona. 


\section{GENERAL ABSTRACT}

The state of Minas Gerais is well known for being a large mining pole, mainly in the socalled quadrilátero ferrífero. In November 2017, the Fundao dam (iron mining) rupture in Mariana - MG, caused one of the biggest environmental disasters in the country, with contamination of the Doce River. Amphibians, as their etymology indicates, are closely associated with aquatic and terrestrial habitats, which makes them vulnerable to almost all types of habitat modification. Among these modifications, those caused by humans such as habitat fragmentation, the introduction of emerging diseases and invasive species, and pollution, can be highlighted as the most worrying. Trace element pollution, for example, can impact the immune response of amphibians, depending on the amount and duration of exposure. Since prolonged exposure to trace elements can cause physiological and morphological changes in animals, including decreased immune response and increased levels of stress mediators, conditions normally found in chronic stress. Therefore, our objective was to evaluate how trace elements present in the Doce River would affect several phenotypic variables of anurans living alongside the river basin. Our hypothesis was that frogs exposed to concentrations of trace elements present in the Doce River would be under chronic stress, associated with reduced reproductive and immunological functions, and reduced intensity of the response to an acute secondary stressor. To test this hypothesis, we analyzed the innate immune response and the plasma concentration of hormones (corticosterone, testosterone, and estradiol), in the basal (field) and post-stress (1h restraint) situations of Rhinella diptycha toads, alongside Doce River. Blood samples were collected before and after restraint, followed by an immunological challenge with the phytohemagglutinin (PHA) mitogen and tissue collection (liver, spleen, and kidneys). The collection sites were subdivided into 3 areas, according to the quantification of the metal in the water and sediment: more contaminated (site 2), intermediate (site 1) and less contaminated (site 3). In general, there was an increase in plasma levels of corticosterone and a reduction in plasma bactericidal capacity of all animals in all areas after restraint. In addition, the frogs from site 3 (less contaminated) showed greater edema after the challenge with PHA and a greater Neutrophil: Lymphocyte ratio post-restraint. Our results indicate that toads living in environments contaminated by trace elements, were able to respond to an acute stressor and to an immunological challenge, however, the response was more effective in animals living in environments with a lower degree of contamination. Thus, we show that as environmental 
contamination by trace elements increases, the immune defense response of toads that live in these environments is less intense, which could compromise their adaptive value.

Keywords: Contamination; Amphibian; Ecoimmunology; Stress; Corticosterone. 


\section{INTRODUÇÃO GERAL}

O estado de Minas Gerais possui as maiores reservas de minérios do Brasil, localizadas principalmente no chamado quadrilátero ferrífero. A região abriga grandes minas de ferro, bem como diversos tipos de rochas e substâncias minerais, tais como ouro, calcário, bauxita, manganês, dentre outros (Prado Filho; Souza, 2004). Os minérios de ferro vêm sendo explorados desde a década de 1940 na região (Silva, 1995), e para que essa mineração ocorra a água é um recurso indispensável. Após a extração e o beneficiamento desses minérios, onde a água é abundantemente utilizada, os efluentes são direcionados para os córregos e rios no entorno dessas mineradoras (Oliveira; Pereira, 2019). Dentre as cidades que compõem o quadrilátero ferrífero estão Belo Horizonte (capital do estado), Nova Lima, Santa Barbara, Ouro Preto, Mariana, dentre outras (Deschamps et al., 2002).

Há cerca de quatro anos (05 de novembro de 2015) o rompimento da barragem de Fundão, localizada no subdistrito de Bento Rodrigues, a $35 \mathrm{~km}$ do centro do município de Mariana/MG, causou um desastre ambiental de grandes proporções, acarretando na contaminação do Rio Doce com metais pesados tais como chumbo $(\mathrm{Pb})$, mercúrio $(\mathrm{Hg})$, ferro (Fe), dentre outros (Segura et al., 2016). Sabe-se que esses metais pesados têm potenciais bioacumulativos (absorção e retenção de substâncias tóxicas por meio de ambiente contaminados), em órgãos tais como fígado e baço de organismos que entram em contato com a água contaminada (Arantes et al., 2016).

O rompimento da barragem impactou aproximadamente 1469 hectares de vegetação e 90\% de habitats ribeirinhos dos rios Gualaxo do Norte e Carmelo, e a lama depositou no Rio Doce quantidades elevadas de metais pesados (Fernandes et al., 2016). Gomes e colaboradores (2017) analisaram a concentração de metais no sedimento do estuário do Rio Doce em Linhares/ES, antes e após a chegada dos rejeitos provenientes da barragem de Fundão. Estes autores observaram que os níveis de bário (Ba), zinco (Zn), $\mathrm{Fe}$, Alumínio ( $\mathrm{Al})$, e cromo $(\mathrm{Cr})$, estavam de duas a cinco vezes mais altos do que os níveis dos mesmos metais medidos dias antes da chagada da lama (Gomes et al., 2017). No dia 25 de janeiro de 2019, outra barragem de minério de ferro rompeu, na cidade de Brumadinho/MG (pertencente também a região do quadrilátero ferrífero), causando o 
assoreamento e contaminação do rio Paraopeba, a morte de centenas de pessoas, e um dano irreparável à fauna e flora local ${ }^{1}$.

Tendo em vista esses desastres, há necessidade de uma fiscalização mais rígida por parte do governo, assim como estudos que visam a fiscalização da qualidade das águas e dos solos de córregos e rios que estão nas adjacências dessas mineradoras. Esses estudos também são importantes, para que possamos ter um maior controle da contaminação, e um melhor entendimento dos seus efeitos sobre a fauna e flora presentes no entorno.

\section{InfluênCia dos Metais Pesados na Fauna}

No que tange à poluição ambiental, a contaminação por metais pesados como $\mathrm{Pb}$, cobre $(\mathrm{Cu})$, cádmio $(\mathrm{Cd})$ e $\mathrm{Zn}$, têm se tornado um problema devido ao aumento de atividades humanas tais como mineração, eliminação de resíduos de fundição, fumaça de exaustão de automóveis, fertilizantes, dentre outros (García-Fernández et al., 2005; Jayawardena et al., 2016). Esses metais, juntamente com mercúrio (Hg), estão entre os poluentes ambientais mais preocupantes em ecossistemas aquáticos, devido à sua persistência no ambiente, seu poder de causar toxicidade aguda e crônica, por serem ubíquos (difundidos extensamente no ambiente) e não-biodegradáveis (Daughton, 2004; Andrews et al., 2013; Jayawardena et al., 2016). Adicionalmente, apresentam um alto potencial bioacumulativo e de biomagnificação (a cada passo da cadeia alimentar, a concentração do metal aumenta nos tecidos orgânicos) (Daughton, 2004; Andrews et al., 2013).

Diversos estudos vêm mostrando os potenciais deletérios dos metais pesados em animais vivendo em locais contaminados (Wayland et al., 2002; Yu et al., 2011; Zhang et al., 2018; Haskins et al., 2017; Xu et al., 2018). A contaminação ambiental por componentes químicos pode resultar em diversas alterações morfológicas e fisiológicas tais como: alteração do tamanho e massa do corpo ou dos órgãos internos (Sparling et al., 2000); mudanças na idade de início da reprodução e do tamanho dos ovos (Zhang et al., 2018); aumento da relação neutrófilo:linfócito (N:L) (variável ligada à resposta ao estresse) (Haskins et al., 2017); acúmulo de metais em órgãos, tais como, fígado e rins

\footnotetext{
1 National Geographic Brasil. Link - https://www.nationalgeographicbrasil.com/meio-
} ambiente/2019/02/uma-semana-apos-tragedia-em-brumadinho-consequencias-ainda-sao-incalculaveis 
(Yu et al., 2011); modulação da imunidade (Wayland et al., 2002); e aumento dos níveis de glicocorticoides (Hopkins et al., 1997).

\section{GLiCOCORTICOIDES, ESTRESSE E IMPACTO AMBIENTAL}

Os glicocorticoides são produzidos pelas glândulas adrenais/inter-renais, e sua secreção é aumentada em resposta a diversos estressores em todos os grupos de vertebrados (Sapolsky et al., 2000). Nesta situação, atuam como importantes mobilizadores de substratos energéticos, além de exercer papel fundamental na modulação e direcionamento da resposta imune no período de recuperação pós-estresse agudo (Sapolsky et al., 2000). Adicionalmente, a exposição a picos muito frequentes, ou a níveis cronicamente elevados destes hormônios, encontra-se associada a efeitos potencialmente deletérios sobre indivíduos e, consequentemente, populações. Esses efeitos deletérios incluem diminuição das taxas de crescimento, inibição da reprodução e depressão da resposta imune (Sapolsky et al., 2000).

Uma vez que os glicocorticoides estão integralmente envolvidos na homeostase, alostase e modulação dos compromissos funcionais e evolutivos entre sobrevivência e reprodução (Angelier; Wingfield, 2013; Wingfield, 2013), o monitoramento dos níveis circulantes destes hormônios pode fornecer valiosos indicadores da resposta a alterações ambientais (Romero; Wikelski, 2001; Hammond et al., 2015). Com isso, medidas dos níveis plasmáticos de glicocorticoides têm sido usadas como um indicador do estresse ambiental gerado a ponto de comprometer o valor adaptativo (Romero; Wikelski, 2001). Altos níveis destes hormônios no plasma já foram encontrados em populações de corujas, peixes e anuros vivendo em ambientes impactados por fragmentação de hábitats, metais pesados (Cd e Zn) e contaminação por resíduos de combustão de carvão, respectivamente (Wasser et al., 1997; Norris et al., 1997; Hopkins et al., 1997).

Associada aos níveis de glicocorticoides, a relação N:L têm se mostrado como um importante parâmetro para avaliar os níveis de estresse em vertebrados (Dhabhar, 2002; Davis et al., 2008; Davis; Maney, 2018). O aumento dos níveis de glicocorticoides na corrente sanguínea induz o aumento da adesão de linfócitos às células endoteliais dos vasos sanguíneos, que migram para os órgãos linfoides, medula óssea e pele; com isso causando uma redução dos linfócitos circulantes (Dhabhar, 2002; Davis et al., 2008). Já com os neutrófilos acontece o inverso, o aumento dos glicocorticoides aumenta o fluxo dessas células para a corrente sanguínea. Essas células são fagócitos, contribuindo desta 
forma para a proteção contra possíveis patógenos que entrem na corrente sanguínea (Wright, 2001; Davis et al., 2008). Como consequência, a relação N:L é alterada em resposta a um estressor devido à redistribuição destas células imunes.

Em contextos de estresse induzido, estudos encontraram uma elevação da concentração plasmática de corticosterona (principal glicocorticoide em anfíbios) e da relação N: L em resposta a um estressor agudo (24h de restrição de movimentos) para diferentes espécies de sapos do gênero Rhinella (Assis et al 2015; Assis et al., 2019). Essa resposta foi acompanhada de diminuição da capacidade bactericida plasmática (CBP) em alguns casos (Assis et al., 2019). Considerando a exposição prolongada a um estressor (manutenção em cativeiro por um longo período), normalmente encontramos redução da resposta imune em anfíbios. Como exemplo, sapos da espécie $R$. diptycha mantidos por 30 dias em cativeiro apresentaram um aumento de 2,5 vezes nos níveis plasmáticos de corticosterona e diminuição de $8 \%$ da CBP e de $18 \%$ na eficiência de fagocitose de células peritoneais (Titon et al., 2017). Outros estudos mostram que indivíduos da espécie $R$. icterica após dois e três meses de cativeiro apresentaram níveis moderadamente elevados de corticosterona plasmática (3 vezes mais altos que os níveis de referência encontrados no campo), e redução de $41 \%$ da CBP e de $15 \%$ na porcentagem de fagocitose de células peritoneais (Assis et al., 2015; Titon et al., 2018). Os estudos acima enfatizam a importância do tipo e duração da exposição a um determinado estressor sobre a intensidade da imunossupressão decorrente do processo.

Diferentemente destes efeitos imunossupressores, a exposição aguda a níveis elevados e transientes de corticosterona através do uso da aplicação transdérmica de corticosterona (hormônio exógeno), promoveu aumento da resposta imune de sapos, neste caso medida como a atividade fagocítica de células do sangue (Assis et al., 2017). Outro estudo, conduzido por Falso et al. (2015), também mostra o efeito imunoestimulador dos glicocorticoides em Rana (Lithobates) catesbeiana, submetidos à exposição de corticosterona exógena de forma aguda e crônica. Neste estudo, os animais que receberam implantes de corticosterona, apresentaram um aumento crônico nos níveis desse hormônio, 14 e 28 dias após o implante, associado com um aumento do número de neutrófilos e da relação $\mathrm{N}: \mathrm{L}$, os quais estavam positivamente correlacionados com a atividade fagocítica dos leucócitos sanguíneos (Falso et al., 2015).

Metais pesados também podem influenciar nos níveis de estresse, estimados através das medidas de concentração plasmática de corticosterona, e na imunidade de aves da espécie Somateria mollissima borealis (Wayland et al., 2002). Nesse estudo com 
aves, a concentração de selênio (Se) no sangue estava positivamente correlacionado com a intensidade do edema causado pela injeção de fitohemaglutinina (PHA), um importante mitógeno de células T (Wayland et al., 2002). Em experimentos feitos com larvas de zebrafish, os pesquisadores observaram que metais $(\mathrm{Hg}, \mathrm{Cd}, \mathrm{Cu}, \mathrm{Cr}, \mathrm{Zn}, \mathrm{Pb}$ ), em concentrações maiores do que encontrados dissolvidos na água no ambiente, promovem um aumento do número de neutrófilos circulantes (Xu et al., 2018). Adicionalmente, os metais $\mathrm{Cu}$ e $\mathrm{Cd}$ aumentaram significativamente os níveis de transcrição de genes ligados à imunidade, como genes codificadores de lisozima, mieloperoxidase, interleucina $8 \mathrm{e}$ fator de necrose tumoral alfa (TNF $\alpha$ ) nestes peixes (Xu et al., 2018). Conforme descrito nos exemplos acima, as interações entre os sistemas endócrino e imune por si, e em contextos de contaminação são complexas, e investigações adicionais nesta área são necessárias para que possamos entender melhor como estes processos funcionam nos anfíbios.

\section{ANuros COMO Modelo PaRa ESTUdar os EFEITOS da CONTAMinaÇÃo Ambiental POR Metais}

Os anuros, por possuírem um ciclo de vida que envolve estágios em ambiente aquático na maior parte das espécies, bem como por possuir uma pele com alta permeabilidade em comparação a outros tetrápodes, são muito sensíveis à contaminação, sendo por isso considerados espécies bioindicadoras e sentinelas de ambientes aquáticos (Sparling et al., 2000; Jayawardena et al., 2016).

A poluição por metais pesados pode influenciar diversos aspectos funcionais em anfíbios, tais como potencial reprodutivo, estado nutricional, capacidade de resposta imune, alterações em funções endócrinas, dentre outros (Hopkins et al., 1997; Linzey et al., 2003; Guo et al., 2018). No tocante à reprodução, a poluição por metais pesados causou mudanças reprodutivas em fêmeas e machos da espécie Strauchibufo (Bufo) raddei (Zhang et al., 2018; Guo et al., 2018). Fêmeas no local contaminado apresentaram ovos menores, mas em maiores quantidades (Zhang et al., 2018), enquanto os machos apresentaram vocalização com maior duração e aumento da força no braço (necessária para o amplexo), em detrimento da longevidade e condição corpórea (Guo et al., 2018), quando comparados com fêmeas e machos dos locais de referência (Zhang et al., 2018; Guo et al., 2018). 
Esses contaminantes também interferem no desenvolvimento gonadal em girinos machos da espécie Pelophylax nigromaculatus (iniciando a fase de absorção da cauda) prejudicando o desenvolvimento dos túbulos seminíferos, além de causar a má-formação de outros órgãos, tais como fígado e rins (Huang et al., 2014). No fígado de Rhinella marina e Eleutherodactylus johnstonei, metais $(\mathrm{Cd}, \mathrm{Cr}$ e $\mathrm{Pb})$ acarretaram em redução das reservas de glicogênio e encolhimento das células dos cordões hepatocitários, indicando má-nutrição ou alteração na capacidade de absorver nutrientes, devido a padrões alterados na alimentação e/ou metabolismo (Linzey et al., 2003). Além disso, Prokić e colaboradores (2016a) afirmaram que a exposição crônica a metais pesados ( $\mathrm{Pb}, \mathrm{Hg}, \mathrm{Fe}$, $\mathrm{Cr}, \mathrm{Zn}, \mathrm{Cu}, \mathrm{Cd}$, cobalto - Co, níquel - Ni, arsênio - As) induz o estresse oxidativo na pele do ventre e no músculo da perna de anuros do complexo Pelophylax esculentus. Os mesmos autores afirmam, que a pele é o órgão mais suscetível à exposição crônica pela maioria dos metais, com exceção do As, que se concentra em maiores quantidades nos músculos (Prokić et al., 2016b).

Anfíbios da espécie Bufo (Anaxyrus) terrestris vivendo em locais contaminados por cinzas de combustão de carvão, bem como metais pesados, apresentaram altos níveis plasmáticos de corticosterona e testosterona quando comparados com indivíduos de pontos de referência (Hopkins et al., 1997). Tais alterações endócrinas foram interpretadas pelo autores como sendo possivelmente decorrentes de condições crônicas de estresse e desregulação da via de produção de esteroides devido à presença dos elementos traço (Hopkins et al., 1997). Além de alterações nos níveis de glicocorticoides como resposta a um estressor, exposição a metais pesados $(\mathrm{Cd}, \mathrm{Cr}, \mathrm{Cu}, \mathrm{Zn}, \mathrm{Pb})$, em campo e laboratório, também causa um aumento da relação $\mathrm{N}: \mathrm{L}$ circulante em anuros da espécie Euphlyctis hexadactylus (Ranidae) (Jayawardena et al., 2016).

Em relação à imunossupressão associada à exposição a metais pesados, alguns estudos têm demonstrado efeitos sobre atividade celular e alteração na produção de mediadores inflamatórios em anuros (Linzey et al., 2003; Carvalho et al., 2016; Jayawardena et al., 2016). Jayawardena e colaboradores (2016) relataram a diminuição da contagem de esplenócitos, e uma alta produção de citocinas pró-inflamatórias como interferon gama e $\mathrm{TNF} \alpha$, indicando injúria no fígado e um aumento da resposta inflamatória associada à exposição aos metais pesados testados em E. hexadactylus. Em $R$. marina, a presença de Cd reduziu a proliferação in vitro de linfócitos $\mathrm{B}$ em resposta a um desafio com lipopolissacarídeo (LPS) (Linzey et al., 2003). 
Outros autores observaram que a exposição de girinos de L. catesbeianus a metais, tais como $\mathrm{Zn}, \mathrm{Cu}$ e $\mathrm{Cd}$, promoveu aumento do número de linfócitos e diminuição do número de neutrófilos, eosinófilos, basófilos e monócitos circulantes (Carvalho et al., 2016). Sabe-se que os neutrófilos e monócitos são células fagocíticas e que eosinófilos estimulam a liberação de histaminas em caso de infecção parasitária (Wright, 2001), com isso metais, tais como $\mathrm{Zn}, \mathrm{Cu}$ e $\mathrm{Cd}$ podem diminuir a resposta imune celular de anfíbios. Metais pesados podem também causar hipoplasia linfóide esplênica, acarretando em depressão da imunidade de rãs e sapos (Linzey et al., 2003). Sendo assim, a presença destes metais no ambiente poderia induzir a diminuição dessas células, acarretando em redução da resposta imune celular de anfíbios da espécie L. catesbeianus (Carvalho et al., 2016).

Com o intuito de entender melhor como a contaminação ambiental por elementos traço influencia a fisiologia de anuros, o presente estudo pretendeu analisar se a liberação desses elementos, causados pela ruptura da barragem de Fundão, afetou aspectos do fenótipo de sapos da espécie Rhinella diptycha encontrados ao longo da bacia do rio Doce. Entre elas, aspectos associados à resposta imune inata e a concentração plasmática de glicocorticoides e esteroides sexuais, tanto em situação basal de campo e pós-submissão a estressor agudo (restrição de $1 \mathrm{~h}$ ), além da bioacumulação de elementos traço no fígado e possíveis alterações morfológicas (aumento dos rins e fígado, e diminuição do baço). Nossas previsões foram: 1. Os parâmetros relacionados à resposta ao estresse (níveis de corticosterona e relação $\mathrm{N}: \mathrm{L}$ ) seriam maiores e os hormônios sexuais (testosterona e estradiol) e resposta imune (CBP e edema causado PHA) seriam menores no local mais próximo da ruptura da barragem; 2. Após um estressor agudo (restrição de 1 hora), todos os animais apresentariam um aumento nos parâmetros de estresse e uma diminuição na resposta imune, e a intensidade de resposta seria menor nos indivíduos mais próximos à ruptura da barragem; 3. Indivíduos vivendo perto da barragem apresentariam maior bioacumulação de elementos traço e alterações morfológicas mais pronunciadas, como fígados e rins maiores e baços menores. Esse estudo está estruturado em um capítulo em forma de artigo a ser submetido ao periódico Ecotoxicology and Environmental Safety. 


\section{REFERÊNCIAS GERAIS}

Andrews, J. E. et al. The Chemistry of Continental Waters. 2013. In: ANDREWS et al. An introduction to environmental chemistry. John Wiley \& Sons, 2013.

Angelier, F.; Wingfield, J.C. Importance of the glucocorticoid stress response in a changing world: theory, hypotheses and perspectives. Gen. Comp. Endocrinol., v. 190, p. 118-128, 2013.

Arantes, F.P. et al. Bioaccumulation of mercury, cadmium, zinc, chromium, and lead in muscle, liver, and spleen tissues of a large commercially valuable catfish species from Brazil. An. Acad. Bras. Ciênc., v. 88, n. 1, 2016.

Assis, V. R., et al. Corticosterone transdermal application in toads (Rhinella icterica): Effects on cellular and humoral immunity and steroid plasma levels. Journal of Experimental Zoology Part A: Ecological and Integrative Physiology, 2017.

Assis, V. R., et al. Effects of Acute Restraint Stress, Prolonged Captivity Stress and Transdermal Corticosterone Application on Immunocompetence and Plasma Levels of Corticosterone on the Cururu Toad (Rhinella icterica). Plos One, v. 10, 2015.

Assis, V. R.; Titon, S. C. M.; Gomes, F. R. Acute stress, steroid plasma levels, and innate immunity in Brazilian toads. General and comparative endocrinology, v. 273, p. 8697, 2019.

Carvalho, C. S. et al. Blood cell responses and metallothionein in the liver, kidney and muscles of bullfrog tadpoles, Lithobates catesbeianus, following exposure to different metals. Environmental Pollution, v. 221, p. 445-452, 2016.

Da Silva, O. P. A mineração em minas gerais: passado, presente e futuro. Revista Geonomos, v. 3, n. 1, 1995.

Daughton, C. G. Non-regulated water contaminants: emerging research. Environmental Impact Assessment Review v. 24, p. 711-732, 2004.

Davis, A. K.; Maney, D. L. The use of glucocorticoid hormones or leucocyte profiles to measure stress in vertebrates: What's the difference?. Methods in Ecology and Evolution, v. 9, n. 6, p. 1556-1568, 2018.

Davis, A. K.; Maney, D. L.; Maerz, J. C. The use of leukocyte profiles to measure stress in vertebrates: a review for ecologists. Functional Ecology, v. 22, n. 5, p. 760-772, 2008.

Deschamps, E. et al. Soil and sediment geochemistry of the iron quadrangle, Brazil the case of arsenic. Journal of soils and sediments, v. 2, n. 4, p. 216-222, 2002.

Dhabhar, F. S. A hassle a day may keep the doctor away: stress and the augmentation of immune function. Integrative and Comparative Biology, v. 42, n. 3, p. 556-564, 2002.

Falso, P. G. et al. The effect of long-term corticosterone treatment on blood cell differentials and function in laboratory and wild-caught amphibian models. General and comparative endocrinology, v. 212, p. 73-83, 2015.

Fernandes, G. W., et al. Deep into the mud: ecological and socio-economic impacts of the dam breach in Mariana, Brazil. Natureza \& Conservação, v. 14, p. 35-45, 2016.

Garcia-Fernandez, A. J., et al. High levels of blood lead in griffon vultures (Gyps fulvus) from Cazorla Natural Park (southern Spain). Environmental Toxicology, v. 20, p. 459-463, 2005.

Gomes, L. E. O. et al. The impacts of the Samarco mine tailing spill on the Rio Doce estuary, Eastern Brazil. Marine pollution bulletin, v. 120, n. 1-2, p. 28-36, 2017.

Guo, R. et al. Variation of fitness and reproductive strategy in male Bufo raddei under environmental heavy metal pollution. Ecotoxicology and environmental safety, v. 164, p. 253-260, 2018. 
Hammond, T.T.; Palme, R.; Lacey, E.A. Contrasting stress responses of two co-occurring chipmunk species (Tamias alpinus and T. speciosus). Gen. Comp. Endocrinol., v. 211, p. 114-122, 2015.

Haskins, D. L. et al. Effects of selenium exposure on the hematology, innate immunity, and metabolic rate of yellow-bellied sliders (Trachemys scripta scripta). Ecotoxicology, v. 26, n. 8, p. 1134-1146, 2017.

Hopkins, W.A.; Mendonça, M.T.; Congdon, J.D. Increased circulating levels of testosterone and corticosterone in southern toads, Bufo terrestris, exposed to coal combustion waste. Gen. Comp. Endocrinol., v. 108, p. 237-246, 1997.

Huang, M.; Duan, R.; Ji, X. The influence of long-term cadmium exposure on phonotaxis in male Pelophylax nigromaculata. Chemosphere, v. 119, p. 763-768, 2014.

Jayawardena, U. A., et al. Heavy metal mediated innate immune responses of the Indian green frog, Euphlyctis hexadactylus (Anura: Ranidae): Cellular profiles and associated Th1 skewed cytokine response. Science of The Total Environment, v. 566, p. 11941204, 2016.

Linzey, D., et al. Role of environmental pollutants on immune functions, parasitic infections and limb malformations in marine toads and whistling frogs from Bermuda. International journal of environmental health research, v. 13, n. 2, p. 125-148, 2003.

Norris, D.O., et al. Immunocytochemical and histological differences in the interrenal axis of feral brown trout, Salmo trutta, in metal-contaminated waters. Gen. Comp. Endocrinol., v. 108, p. 343-351, 1997.

Oliveira, G. S.; Pereira, A. A. Efeitos da implantação e operação do complexo minerário do sistema Minas-Rio na qualidade das águas superficiais. Holos Environment, v. 19, n. 1, p. 22-41, 2019.

Prado Filho, J. F.; Souza, M. P. O licenciamento ambiental da mineração no Quadrilátero Ferrífero de Minas Gerais-uma análise da implementação de medidas de controle ambiental formuladas em EIAS/RIMAs. Eng. sanit. ambient., v. 9, n. 4, p. 343-349, 2004.

Prokić, M. D., et al. Antioxidative responses of the tissues of two wild populations of Pelophylax kl. esculentus frogs to heavy metal pollution. Ecotoxicology and environmental safety, v. 128, p. 21-29, 2016a

Prokić, M. D., et al. Bioaccumulation and effects of metals on oxidative stress and neurotoxicity parameters in the frogs from the Pelophylax esculentus complex. Ecotoxicology, v. 25, p. 1531-1542, 2016b.

Romero, L.M.; Wikelski, M. Corticosterone level predict survival probabilities of Galapagos marine iguanas during El Niño events. PNAS, v. 98, p. 7366-7370, 2001.

Sapolsky, R.M.; Romero, L.M.; Muck, A.U. How do glucocorticoids influence stress responses? Integrating permissive, suppressive, stimulatory, and preparative actions. Endocrinol. Rev. v. 21, p. 55-89, 2000.

Segura, F.R., et al. Potential risks of the residue from the Samarco's mine dam burst (Bento Rodrigues, Brazil). Environmental Pollution, v. 218, p. 813-825, 2016.

Sparling, D. W.; Linder, G.; Bishop, C. A. (eds). Ecotoxicology of amphibians and reptiles. Pensacola, FL: Society of Environmental Toxicology and Chemistry (SETAC). p. 15-71, 2000.

Titon, S. C. M. et al. Captivity effects on immune response and steroid plasma levels of a Brazilian toad (Rhinella schneideri). Journal of Experimental Zoology Part A: Ecological and Integrative Physiology, v. 327, n. 2-3, p. 127-138, 2017.

Titon, S. C. M. et al. Interplay among steroids, body condition and immunity in response to long-term captivity in toads. Scientific reports, v. 8, n. 1, p. 17168, 2018. 
Wasser, S.K., et al. Noninvasive physiological measures of disturbance in the Northern Spotted Owl. Cons. Biol., v. 11, p. 1019-1022, 1997.

Wayland, M. et al. Immune function, stress response, and body condition in arcticbreeding common eiders in relation to cadmium, mercury, and selenium concentrations. Environmental Research, v. 90, n. 1, p. 47-60, 2002.

Wingfield, J.C. The comparative biology of environmental stress: Behavioral endocrinology and variation in ability to cope with novel, changing environments. Anim. Behav., v. 85, p. 1127-1133, 2013.

Wright, K. M. Amphibian hematology. Amphibian Medicine and Captive Husbandry. KM Wright and BR Whitaker (eds). Krieger Publ. Co., Malabar, Florida, p. 129-146, 2001.

$\mathrm{Xu}, \mathrm{H}$. et al. Immune response induced by major environmental pollutants through altering neutrophils in zebrafish larvae. Aquatic toxicology, v. 201, p. 99-108, 2018.

$\mathrm{Yu}, \mathrm{S}$. et al. Metal accumulation and evaluation of effects in a freshwater turtle. Ecotoxicology, v. 20, n. 8, p. 1801-1812, 2011.

Zhang, W. et al. Long-term heavy metal pollution varied female reproduction investment in free-living anura, Bufo raddei. Ecotoxicology and environmental safety, v. 159, p. 136-142, 2018. 


\section{Journal: Ecotoxicology and Environmental Safety}

\section{Negative influence of trace elements on steroid hormones, immunity and organ mass in toads}

Ronyelle Vasconcelos-Teixeira ${ }^{1 *}$, Stefanny C. M. Titon ${ }^{1,2}$, Braz Titon $\mathrm{Jr}^{3}$, Marcelo L. M. Pompêo ${ }^{4}$, Fernando R. Gomes ${ }^{1}$ and Vania R. Assis ${ }^{1}$

${ }^{1}$ Laboratory of Behavior and Evolutionary Physiology, Department of Physiology, Institute of Biosciences, University of São Paulo, São Paulo, Brazil.

${ }^{2}$ Laboratory of Disease \& Drug-Associated Receptors Knowledge, Department of Physiology, Institute of Biosciences, University of São Paulo, São Paulo, Brazil.

${ }^{3}$ Laboratory of Ecophysiology and Evolutionary Physiology, Department of Physiology, Institute of Biosciences, University of São Paulo, São Paulo, Brazil.

${ }^{4}$ Laboratory of Limnology, Department of Ecology, Institute of Biosciences, University of São Paulo, São Paulo, Brazil.

*Corresponding author: Ronyelle Vasconcelos-Teixeira,

E-mail: ronyellevasconcelos@gmail.com

Address: Laboratório de Comportamento e Fisiologia Evolutiva, lab. 206.

Departamento de Fisiologia, Instituto de Biociências, Universidade de São Paulo.

Rua do Matão, Tr. 14, N. 101, São Paulo 05508-900, Brazil.

\section{Abstract}

Mining is one of the main activities that drive Brazil's economy. Associated with this activity is the risk of environmental contamination by trace elements, and consequently the local fauna. Amphibians have a life cycle that transits between aquatic and terrestrial environments, increasing their vulnerability to several forms of habitat modification, including contamination by trace elements. Metals are ubiquitous, with high bioaccumulative and biomagnifying potential, and may lead to immune and endocrine disruption. In this study, we analyzed the innate immune response and plasma hormonal levels (corticosterone, estradiol and testosterone), at baseline (field) and post-stress (1h restraint) situations, of amphibians living in places contaminated by trace elements. Blood samples were collected before and after restraint, followed by an immune challenge with the mitogen phytohemagglutinin (PHA), and tissue collection (liver, spleen, and kidneys). The collection sites were sampled and then subdivided into 3 areas according to the metal quantification in water and sediment: more contaminated (site 2), intermediate (site 1) and less contaminated (site 3). In general, there was an increase in corticosterone plasma levels and a reduction in the bactericidal killing ability of all animals in all areas after 
restraint. Additionally, toads living on site 3, the less contaminated, showed greater edema after the PHA challenge and increased in N: L post-restraint. Our results indicate that even living in environments contaminated by trace elements, animals were able to respond to an acute stressor and an immunological challenge, and the response was more effective in those individuals living in the less contaminated environment.

KEYWORDS: Contamination; Stress; Immunological challenges; Ecoimmunology; Anurans.

\section{INTRODUCTION}

Mineral ores are the main raw material for industrial applications and technology development (Hatje et al., 2017). Mining is known to impact the ecosystem with its trace elements, especially with the ruptures of dams, causing the contamination of freshwater and the biodiversity around, leading to trace elements incorporation in the trophic chain and, in some cases, to death (Bottino et al., 2017; Hatje et al., 2017; Otero et al., 2018). Environmental contamination by trace elements can adversely affect the exposed fauna, promoting stress response and endocrine dysregulation (Haskins et al., 2017; Hopkins et al., 1997; Jayawardena et al., 2016; Linzey et al., 2003; Wayland et al., 2002).

Glucocorticoids are constantly released in small quantities by the adrenal/interrenal glands and show a circadian secretion rhythm (Barriga et al., 2001). When facing an adverse situation, the initial activation of the hypothalamic-pituitaryadrenal/interrenal (HPA/I) axis is adaptive and aims to help organisms to cope with challenges (Romero \& Wingfield, 2015). However, prolonged activation of the HPA/I axis in response to several stressors, including organisms facing environmental pollution (Hopkins et al., 1997; Norris et al., 1997; Sapolsky et al., 2000; Wayland et al., 2002), can disrupt several functions, such as reproduction and immune response (Hopkins et al., 1997; Jayawardena et al., 2016). 
In this context, increased activity of HPA/I axis can inhibit the activity of the hypothalamic-pituitary-gonadal axis, leading to decreased secretion of sexual hormones and, consequently, disrupting sexual behavior and reproductive output (Guo et al., 2018; Hopkins et al., 1997; Wingfield, 2013; Zhang et al., 2018). Besides promoting stress and endocrine dysregulation, trace elements in the environment can accumulate in several organs, such as kidneys, liver, and spleens (Arantes et al., 2016; Prokić et al., 2016b; Yu et al., 2011), which promote malformation (Huang et al., 2014; Linzey et al., 2003; Yu et al., 2011; Zhelev et al., 2015) and reduce energy reserves (Linzey et al., 2003). Moreover, contamination by trace elements are associated with increased depuration in kidneys and liver (Arantes et al., 2016; Haskins et al., 2017; Yu et al., 2011); and with spleen mass reduction, which could lead to immunosuppression (Linzey et al., 2003).

Playing an important role in the organismal surveillance and defense against foreign agents, the immune system is subjected to a complex modulation by several hormones, including glucocorticoids (Dhabhar, 2002; Romero \& Wingfield, 2015). Increased circulating glucocorticoid levels induce the migration of lymphocytes to the peripheral organs and an influx of neutrophils in the bloodstream (Davis \& Maney, 2018; Dhabhar, 2002). Neutrophils are phagocytic cells, and an elevation of its circulating levels contributes to protection against possible pathogens that may enter the bloodstream (Davis \& Maney, 2018; Wright, 2001). Several studies have shown glucocorticoid enhances immune response when animals are exposed to acute stressors (Dhabhar \& McEwen, 1999; Dhabhar, 2014). Otherwise, chronically enhanced glucocorticoid secretion in response to chronic stressors promotes immunosuppression (Dhabhar, 2014; Falso et al., 2015; Titon et al., 2017). Moreover, individuals exposed to chronic stressors may fail to mount an effective stress response when faced with an additional acute stressor, reducing fitness (Romero \& Wingfield, 2015). 
Among tetrapods, amphibians are generally characterized by a life cycle that transits between aquatic and terrestrial stages and high skin permeability, making them highly sensitive to environmental contamination (Jayawardena et al., 2016; Sparling et al., 2000). Several studies have reported endocrine dysregulation in amphibians exposed to environmental contamination, including increased glucocorticoid levels and disruption of reproductive features (Guo et al., 2018; Hopkins et al., 1997; Wayland et al., 2002). Moreover, the exposure of amphibians to trace elements can also alter cellular activity, impacting the production of inflammatory mediators. And with this inducing a reduction of circulating leukocytes, and leading to decreased cellular immune response (Carvalho et al., 2017; Jayawardena et al., 2016; Linzey et al., 2003).

Since the $17^{\text {th }}$ century, Brazil's economy has been driven by mining, with the State of Minas Gerais as the main mining pole in the country (Machado \& Silvia, 2001). In November of 2015 a dam, of iron mining, busted (Fundão dam) in the municipality of Mariana, the state of Minas Gerais. It's rupture caused an environmental disaster of great proportion and contaminated a very important River basin (Doce River basin) in Brazil with iron ore waste (Segura et al., 2016). This rupture led to an increase in the concentration of aluminum, chromium, iron, and zinc in Doce River water (Gomes et al., 2017). In this context, our goal was to investigate how trace elements present at Doce River affected several aspects of the anuran phenotype found along the River basin. We hypothesize that anurans exposed to trace elements concentrations in Doce River would be under chronic stress, associated with reduction of reproductive and immune functions, and reduction in the intensity of response to a secondary acute stressor.

To test this hypothesis, we sampled toads (Rhinella diptycha) in different localities along Doce River and measured variables associated with innate immune response [plasma bacterial killing ability (BKA) and edema induced by phytohemagglutinin (PHA) 
injection], stress response [plasma glucocorticoids levels (corticosterone - CORT) and neutrophil: lymphocyte ratio $(\mathrm{N}: \mathrm{L})$ ], and sexual steroids [plasma testosterone $(\mathrm{T})$ and estradiol (E) levels], in a baseline and post-submission to acute stressor (restraint) situations. We also measured the relative masses of kidneys, liver, and spleen; as well as metal bioaccumulation in the liver. Samples of water and sediment were also collected in the same localities for measurements of trace elements. Our predictions were: 1 . The parameters related to stress response would be higher and the sex hormone levels and the immune response would be lower at the site closer to the dam rupture; 2 . After an acute stressor (1-hour restraint challenge) all animals would show an increase in the stress parameters, and the intensity of response would be lower at the individuals closer to the dam rupture; 3. Individuals living near the dam would present higher levels of trace elements bioaccumulation and more pronounced morphological alterations, such as larger livers and kidneys and smaller spleens; 4. Individuals with higher levels of bioaccumulated trace elements would show lesser response to an acute stressor, lower immune response and sex hormone levels, and less intense edema induced by a mitogen (which is an indirect measurement of cellular immune response); and 5. Trace elements in water and sediment along the Doce River would be more concentrated in the localities closer to the dam rupture.

\section{MATERIALS AND METHODS}

\subsection{STUdY Site}

Three sites alongside the Doce River were chosen to evaluate the contamination in places affected by the Fundão dam rupture. The first locality is within the municipality of Ipatinga $\left(19^{\circ} 28^{\prime} 08^{\prime \prime} \mathrm{S}\right.$ and $\left.42^{\circ} 32^{\prime} 12^{\prime \prime} \mathrm{W}\right), 194 \mathrm{~km}$ away from the dam rupture. The second locality is within the municipality of Governador Valadares (18 $51^{\prime} 02^{\prime \prime} \mathrm{S}$ and $\left.41^{\circ} 56^{\prime} 53^{\prime \prime} \mathrm{W}\right), 287 \mathrm{~km}$ away from the dam rupture. Both localities are situated in the state 
of Minas Gerais. The third locality is within the municipality of Linhares (19²3'27’S and $\left.40^{\circ} 04^{\prime} 13^{\prime \prime} \mathrm{W}\right)$, near the River estuary and $549 \mathrm{~km}$ away from the dam rupture, at the state of Espírito Santo (Figure 1). At those sites were collected water and sediment to verify the trace elements concentration in the River basin. Water quality parameters were measured at each site during collection $\left[\mathrm{pH}\right.$, temperature $\left({ }^{\circ} \mathrm{C}\right)$ and dissolved oxygen (DO)].

The animals were captured in the cities of Governador Valadares (site 1) and Linhares (sites 2 and 3). Site 1 was near a lake located on a farm $\left(18^{\circ} 42^{\prime} 48,7^{\prime \prime}\right.$ S and $42^{\circ} 00$ '39,4'W), $29 \mathrm{~km}$ away from the Doce River. Site 2 was located at the banks of the Doce River $\left(19^{\circ} 25^{\prime} 33,2^{\prime \prime} \mathrm{S}\right.$ and $\left.40^{\circ} 05^{\prime} 43,7^{\prime \prime} \mathrm{W}\right)$, and site 3 was a lagoon located at $17 \mathrm{~km}$ away from site $2\left(19^{\circ} 18^{\prime} 15,5^{\prime} \mathrm{S}\right.$ and $\left.40^{\circ} 05^{\prime} 08,0^{\prime \prime} \mathrm{W}\right)$. Samples of water and sediment were also collected in each of the sites where the animals were collected. We did not find animals in the city closer to the dam rupture (Ipatinga).

\subsection{WATER AND SEDIMENT PROCESSING FOR TRACE ELEMENTS QUANTIFICATION}

Samples of water and sediment were collected at the riverbanks and analyzed to determine the level of contamination by trace elements in all collection sites. Water samples for trace element analyses were collected in amber containers $(300 \mathrm{~mL}$ plastic bottles), previously washed with $10 \%$ nitric acid (HNO3). Subsequently, $0.6 \mathrm{~mL}$ of $\mathrm{HNO}_{3}$ was added to each flask for $\mathrm{pH}$ reduction $(\mathrm{pH}=2)$. The samples were stored in iceboxes during the sampling period and in the transport to the laboratory. In the laboratory, to every $100 \mathrm{~mL}$ of the water samples were added $2 \mathrm{~mL}$ of $\mathrm{HNO}_{3}$ and $5 \mathrm{~mL}$ of $\mathrm{HCl}$ and digested (in duplicate) in a beaker in a $90^{\circ} \mathrm{C}$ sand bath until the volume was reduced to about 15 or $20 \mathrm{~mL}$ (APHA, 1998).

Sediment samples were collected in plastic pots and with the aid of a PVC pipe previously washed with $10 \% \mathrm{HNO}_{3}$. With the pipe, the sediment was excavated and 
transferred into the pot, avoiding the direct handling of the soil. In the laboratory, $2 \mathrm{~g}$ of the dried and comminuted sample was weighed and $9 \mathrm{~mL}$ of concentrated $\mathrm{HNO}_{3}$ and 1 $\mathrm{mL}$ of $\mathrm{HCl}$ were added and digested in a microwave MARS 6 for 10 min heating to $180^{\circ} \mathrm{C}$, and additional $15 \mathrm{~min}$ at that temperature (standard method for the microwave digestion of sediment). Water and sediment samples were then filtered through Whatman filters (Ashless 42, of $125 \mathrm{~mm}$ ) and the volumes adjusted to $25 \mathrm{~mL}$. Then the samples were maintained at $4{ }^{\circ} \mathrm{C}$ until the moment of analysis by atomic emission spectrometry with inductively coupled plasma (ICP-OES; APHA, 1998). The concentrations of Aluminum (Al), Calcium (Ca), Cadmium (Cd), Cobalt (Co), Chromium (Cr), Copper $(\mathrm{Cu})$, Iron $(\mathrm{Fe})$, Magnesium $(\mathrm{Mg})$, Manganese $(\mathrm{Mn})$, Nickel (Ni), Lead (Pb) and Zinc ( $\mathrm{Zn}$ ) was read for the water and sediment by ICP-OES (model 710, Agilent Technologies).

\subsection{STUDY SPECIES}

Thirty-two toads of Rhinella diptycha species (previously known as Rhinella schneideri; Lavilla \& Brusquetti, 2018), large toads belonging to Rhinella marina species group (Pramuk, 2006), were collected in January of 2018. The collection of the specimens was approved by the Instituto Chico Mendes de Conservação da Biodiversidade (ICMBio, process 29896-1). The ethical approval for the experiments with the animals was granted by the Ethics Committee on Animal Use of the Bioscience Institute of University of Sao Paulo (CEUA n 303/2017).

\subsection{FIELD PROCEDURES}

Animals collected were of both sexes [Site 1: $\mathrm{n}=10$ ( 2 females and 8 males); site 2: $\mathrm{n}=13$ ( 6 females and 7 males); and site $3: \mathrm{n}=9$ (4 females and 5 males) $)$. Toads were located by visual inspection and hand captured. Blood samples were collected (150 $\mu \mathrm{L})$ by cardiac puncture using heparinized $1 \mathrm{~mL}$ syringes and $26 \mathrm{Gx} 1 / 2^{\prime \prime}$ needles for baseline 
measurements, and then all animals were immediately subjected to an acute stress protocol (movement restriction for $1 \mathrm{~h}$ ), followed by a second blood sample (150 $\mu \mathrm{L})$. The acute stress protocol (restraint) consisted of keeping the toad tied in a moistened cloth bag as described by Assis et al. (2015). Blood samples were collected within 3 min after we start handling the animals, to avoid the increase of CORT levels due to manipulation (Romero \& Reed, 2005). The samples were labeled and kept on ice during the time spent in the field $(\sim 4 \mathrm{~h})$.

A PHA challenge was also performed with 7 animals from site 1 (2 females and 5 males), 8 from site 2 ( 3 females and 5 males) and 7 from site 3 ( 3 females and 4 males). At the end of the PHA challenge, the animals included or not in the PHA challenge, were weighed $(0.01 \mathrm{~g})$, measured the snout-vent length $(\mathrm{SVL}, 0.01 \mathrm{~mm})$ and euthanized by immersion in lethal benzocaine solution $(1 \mathrm{~g} / \mathrm{L})$. The animals were then spinalised for dissection and removal of the organs (spleen, kidneys and liver, $\mathrm{n}=28$ ).

\subsection{TISSUE SAMPLING AND PROCESSING FOR TRACE ELEMENTS QUANTIFICATION}

After euthanasia, organs were dissected (spleen, kidneys, and liver) using nonmetallic surgical material (plastic tweezers and ceramic scissors). These organs were weighed $(0.001 \mathrm{~g})$, stored in cryovials, and kept in liquid nitrogen in the field. At the laboratory, the samples were transferred to a $-80^{\circ} \mathrm{C}$ freezer until processing for the determination of trace elements.

Liver samples were digested following the modified methodology of Prokić et al., (2016a). The organs were dried at $105^{\circ} \mathrm{C}$ to obtain dry weight, macerated, then $0.5 \mathrm{~g}$ of the tissue were digested in a microwave MARS 6 with $8.75 \mathrm{~mL}$ of nitric acid $\left(65 \% \mathrm{HNO}_{3}\right)$ and $1.25 \mathrm{~mL}$ of hydrogen peroxide $\left(30 \% \mathrm{H}_{2} \mathrm{O}_{2}\right)$ for $10 \mathrm{~min}$ heating to $200{ }^{\circ} \mathrm{C}$, and additional $15 \mathrm{~min}$ at that temperature. After cooling at room temperature, the samples 
were filtered in a volumetric flask, and the final volume was adjusted with ultrapure water to $25 \mathrm{~mL}$, then stored at $4{ }^{\circ} \mathrm{C}$ in $50 \mathrm{~mL}$ sterile conical tubes until trace elements quantification (Prokić et al., 2016a). Liver trace elements concentration was done for the same 12 ones read for water and sediment (Section 2.2).

\subsection{BLOOD ISOLATION AND PARAMETERS}

A drop of the blood was used to make a blood smear, for posterior differential cell counting, and the blood was transferred to a microtube, then centrifuged for plasma separation (4 min at $604 \mathrm{~g}$ ). The plasma samples were stored on cryovials and kept in liquid nitrogen until arriving at the laboratory, then transferred to a $-80{ }^{\circ} \mathrm{C}$ freezer.

\subsubsection{Leukocyte profile}

One blood slide of each individual was stained with Giemsa (10\%) and observed under an optical microscope, thus performing differential counting of leukocytes (neutrophils, lymphocytes, eosinophils, monocytes and basophils). One hundred leukocytes were counted and identified morphologically (Campbell, 2006) under an optical microscope (objective of 100x using immersion oil, Nikon E200) and the neutrophil/lymphocyte ratio (N:L) was calculated.

\subsubsection{Bacterial killing ability (BKA)}

This assay was performed with modifications of the procedure used by Assis et al., (2013) to use the pathogenic bacteria Aeromonas hydrophila (IOC / FDA 110-36). The day before the assay, $5 \mu \mathrm{L}$ of stock bacteria (kept in glycerol in the freezer $-80^{\circ} \mathrm{C}$ ) was diluted in $5 \mathrm{~mL}$ of tryptic soy broth (TSB), and this mixture was kept overnight inside an incubator at a constant temperature of $37^{\circ} \mathrm{C}$ (optimum temperature for the growth of A. hydrophila). On the following day, the optical density of the bacteria was verified by spectrophotometry (wavelength $595 \mathrm{~nm}, 96$-well microplate). From this density, serial dilutions were made to obtain the working concentration $\left(2.5 \times 10^{7} \mathrm{~mL}^{-1}\right.$ microorganisms $)$. 
Plasma samples $(10 \mu \mathrm{L})$ were incubated together with the working solution of $A$. hydrophila $(10 \mu \mathrm{L})$ in Ringer's solution for amphibians $(190 \mu \mathrm{L})$ for $1 \mathrm{~h}$ at $37^{\circ} \mathrm{C}$. The positive control of the assay was determined by adding $10 \mu \mathrm{L}$ of $A$. hydrophila to $200 \mu \mathrm{L}$ of Ringer, and for the negative control was used $210 \mu \mathrm{L}$ of Ringer, both controls were incubated under the same conditions as the samples.

After the incubation time, $500 \mu \mathrm{L}$ TSB broth was added to each sample, and duplicates (300 $\mu \mathrm{L}$ per well) were transferred to 96 wells sterile microplates, where they were maintained at $37{ }^{\circ} \mathrm{C}$ for another hour. In the first hour, the plasma in contact with the bacteria performed its bactericidal action; in the second hour, with the addition of TSB (culture medium), the bacteria that were not killed by the plasma antimicrobial action started to grow. After $1 \mathrm{~h}$ of incubation at $37{ }^{\circ} \mathrm{C}$, the plate was read every hour within a $4 \mathrm{~h}$ period in a spectrophotometer, totaling $6 \mathrm{~h}$ of incubation. To account for plasma antimicrobial activity, we used the following formula: [1 - (optical density of sample / optical density of positive control)] and the result represents the proportion of dead bacteria in the sample in relation to the positive control. BKA was evaluated at the beginning of the exponential phase of bacterial growth, corresponding to the time at which BKA can be estimated more appropriately.

\subsubsection{Hormonal Assay}

Steroids were extracted from a $10 \mu \mathrm{L}$ sample of plasma with ether according to Mendonça et al. (1996) and Assis et al. (2017). Briefly, each $10 \mu \mathrm{L}$ of the sample was added $3 \mathrm{~mL}$ of ethyl ether, and the mixture was vortexed for $30 \mathrm{sec}$ and centrifuged (4 ${ }^{\circ} \mathrm{C}, 9 \mathrm{~min}$ at $583 \mathrm{~g}$ ). Next, the samples were decanted in a freezer $-80{ }^{\circ} \mathrm{C}$ for $7 \mathrm{~min}$ and the liquid phase transferred to another tube. These tubes were kept in the laminar flow hood until all the ether evaporated (about $24 \mathrm{~h}$ ). The extracted samples were resuspended in ELISA buffer, and the levels of corticosterone (CORT; \# 501320), testosterone (T; \# 
582701) and estradiol (E; \# 582251) were measured through ELISA kits (Cayman Chemical®) according to the manufacturer's instructions. Intra-assay variation was $5.94 \%$ for CORT, $4.37 \%$ for $\mathrm{T}$, and $8.76 \%$ for E. Inter-assay variation was $6.71 \%$ for CORT, $5.38 \%$ for T, and $7.41 \%$ for E. Sensitivity of the assays, calculated as $80 \%$ of $\mathrm{B} / \mathrm{B}_{0}$ values, were $20.95 \mathrm{pg} / \mathrm{mL}$ for CORT, $13.92 \mathrm{pg} / \mathrm{mL}$ for $\mathrm{T}$, and $32.04 \mathrm{pg} / \mathrm{mL}$ for $\mathrm{E}$.

Additionally, validation of Cayman Chemical kits (CORT, T and E) for $R$. diptycha toads through a parallelism test was made accordingly with Assis et al. (2017). The parallelism test was made with samples from baseline and post-restrained toads (Figure S1).

\subsection{PhYTOHEMAgGLUTININ (PHA) SKIN SWELLING ASSAY}

The immunological challenge with PHA was made to measure the ability of the inflammatory response, through the intensity of the edema resulting from the immunological challenge (Brown et al., 2011; Titon et al., 2016). This procedure was performed according to Titon et al. (2016). Briefly, $10 \mu \mathrm{L}$ of a $20 \mathrm{mg} / \mathrm{mL}$ solution of PHA (Sigma L8754) in sterile saline solution was injected into the right hind paw base of the subjects using a glass syringe and $30 \mathrm{Gx} 1 / 2$ " needle. As a control, $10 \mu \mathrm{L}$ of sterile saline (SAL) was injected into the base of the left hind paw of the same individuals. The injections were performed with a 5 min interval between individuals so that the measurements were obtained in the same interval for all the animals. The thickness of the feet was measured before, $12 \mathrm{~h}$ and $18 \mathrm{~h}$ after the injections using a thickness gauge (Digimess - the accuracy of $0.01 \mathrm{~mm}$ ). The edema in response to PHA injection was calculated by the difference in the thickness of the base of the paws before and after the injections (12 h- $0 \mathrm{~h}$ and $18 \mathrm{~h}-0 \mathrm{~h})$. The thickness of each paw was measured three times, and the mean of the values used for the calculations. 


\subsection{STATISTICAL ANALYSES}

All statistical analyses were performed using the software SPSS statistics 22 for windows. The complete descriptive analyses were made for all the variables, all data were tested for normality and homogeneity of variance, using Shapiro-Wilk and Levine's tests, respectively. All data was normal but presented the absence of homogeneity of variances. Data were then $\log _{10}$ (Mass, SVL, BKA, CORT, T, E, and trace elements) and cubic square (N:L, PHA, and SAL edema) transformed to fit the homogeneity of variances. Outliers identified using a $\mathrm{Z}$ score test were excluded from the analysis. A Linear Discriminant Analyses for multiple groups was conducted using liver bioaccumulation data to evaluate group classification. Liver quantified elements $(\mathrm{Ca}, \mathrm{Cu}, \mathrm{Fe}, \mathrm{Mg}$, and $\mathrm{Zn}$ ) were implemented in a Varimax normalized principal component analysis (PCA), and the scores of components with eigenvalues $>1$ were saved to be used in further analyses.

To investigate baseline differences, a set of ANCOVAs and ANOVAs were performed to analyze differences in BKA, CORT, $\mathrm{N}: \mathrm{L}, \mathrm{T}$, organs relative mass (liver, kidney, and spleen), and liver`s bioaccumulated trace elements ( $\mathrm{Ca}, \mathrm{Cu}, \mathrm{Fe}, \mathrm{Mg}$, and $\mathrm{Zn}$ ). Except for E, where a Student t-test was used, sex (male and female) and location (sites 1, 2, and 3) were used as factors for all analyses. When appropriate, ANOVA tests were followed by tests for mean multiple comparisons with Bonferroni adjustments.

A set of ANCOVAs and Mixed ANOVAs were used to analyze the restraint effect (baseline vs. post-restraint data), as well as, PHA immunological challenge. All the ANOVAs were followed by Bonferroni adjustments. Dependent variables for mixed ANOVAs were: N:L, BKA, CORT, T, E, PHA and SAL edema. Location and sex were used as between-subject factors for all the variables. For BKA, CORT, N:L, E and T, restraint challenge (baseline and post-restraint) was used as within-subject factors. Also, time post-injection (12 h and $18 \mathrm{~h}$ ) was used as an additional factor for PHA and SAL edema. 
For all the ANCOVAs tests, body index (BI), body mass and PCA factor scores were used as covariables to define the final models. BI was considered as the residuals of a linear regression of body mass as a function of SVL. For variables in which there was no effect of sex, the analysis was repeated using only location as factor. The factor sex was also excluded from the analysis when the number of animals was small $(\mathrm{n}=1$ or $\mathrm{n}=$ 2), like in $\mathrm{Zn}$ concentration, PHA and SAL edema. Parametric correlation tests (Pearson`s) between variables influenced by the covariables (BI, mass and/or PCA factor scores) and those covariables were used to determine the direction of the influence. Data were presented at tables as means \pm standard deviation $(\mathrm{SD})$ and at graphics as means \pm standard error (SE).

\section{RESUlts}

\subsection{TRACE ELEMENTS AT THE ENVIRONMENT}

From the twelve investigated trace elements (Al, Ca, Cd, $\mathrm{Co}, \mathrm{Cr}, \mathrm{Cu}, \mathrm{Fe}, \mathrm{Mg}, \mathrm{Mn}$, $\mathrm{Ni}, \mathrm{Pb}$, and $\mathrm{Zn}$ ), only four were detected in water (Table 1), seven in sediment (Table 1) and five in tissue samples (Table S1). The other trace elements showed concentration values below the equipment calibration curve. For the water collected at the sites where animals were found (Sites 1-3), site 1 showed higher trace element concentration, except for $\mathrm{Al}$ (Table 1). The concentration of trace elements in sediment showed a gradient pattern, with higher values found in Linhares (estuary region) and lower values in Ipatinga (closer from the damn rupture; Table 1). For the sediment collected in the sites where animals were found, except for $\mathrm{Ca}$, the concentration of trace elements was higher at site 2 (Linhares, at Doce Riverbanks; Table 1).

\subsection{TRACE ELEMENTS DETECTED IN $R$. diptycha LIVER}

Descriptive statistics of detected liver's trace elements $(\mathrm{Ca}, \mathrm{Cu}, \mathrm{Fe}, \mathrm{Mg}$, and $\mathrm{Zn}$ ) from individuals collected at the three sites are presented in Table S1. The linear 
discriminant analyses for the liver's trace elements showed two discriminant functions. The first function discriminated $93.4 \%$ of the data and the second function only discriminated $6.6 \%$ of the data. Function 1 had the largest absolute correlation with $\mathrm{Ca}$ concentration (Table S2). Function 2 correlated all the other trace elements, where higher $\mathrm{Cu}, \mathrm{Fe}$, and $\mathrm{Mg}$ concentrations are associated with lower $\mathrm{Zn}$ concentration (Table S2). The group classification was $100 \%$ accurate for site $1,84.6 \%$ accurate for site 2 , and $57.1 \%$ accurate for site 3 (Figure S2; Table S3).

PCA analysis grouped the trace elements found in the liver in 2 components and accounted for $59.86 \%$ of the total variation (Table S4). The first component (C1) explained the major source of variation $(36.62 \%)$, showing a positive association between $\mathrm{Mg}$ and $\mathrm{Zn}$ concentration. Component 2 (C2) explained $23.24 \%$ of the variance and showed a positive association between $\mathrm{Cu}$ and $\mathrm{Fe}$. $\mathrm{Ca}$, and $\mathrm{Zn}$ were the liver bioaccumulated metals that differ among sites, with site 1 presenting lower values (Table 2).

\subsection{MORPHOLOGICAL PARAMETERS}

Descriptive statistic of organs relative mass from three sites are presented in Table S1. Liver relative mass was influenced by the covariable $\mathrm{C} 1$ scores (Table 3), with larger livers showing lower concentrations of $\mathrm{Mg}$ and $\mathrm{Zn}(r=-0.536 ; p=0.005)$. Spleen and kidney relative mass were different between the sites (Table 2), spleens were larger in toads from site 3 compared with site 1; and kidneys were larger in toads from site 2 compared with site 3 (Figure $2 \mathrm{~A}$ and $\mathrm{B}$, respectively).

\subsection{Physiological PARAMETERS}

Descriptive statistics of baseline and post-restraint parameters are presented in Table S5 and S6. For baseline parameters, estradiol (E) was influenced by body mass (Table 3), where the higher the baseline $\mathrm{E}$ levels the greater the body mass $(r=0.770 ; p$ 
$=0.009)$. Testosterone was the only baseline parameter that differs among sites $\left(\mathrm{F}_{2,17}=\right.$ 3.738; $p=0.045$ ), with animals from site 2 showing higher $\mathrm{T}$ levels when compared with animals from site 1.

CORT levels increased post-restraint independently of the site (Table 2; Figure 2A). Additionally, pos-restraint $\mathrm{T}$ was different among sites (Table 2), with individuals from sites 2 and 3 showing higher T levels when compared with individuals from site 1 (Figure 3B). Regarding E levels, individuals showed a positive correlation between $\mathrm{E}$ plasma levels and body mass at post-restraint condition $(r=0.849 ; p=0.004)$.

Restraint increased N:L ratio (Table 2), with toads from site 3 showing differences between baseline and post-restraint values (Figure 4A). Moreover, restraint decreased BKA (Table 2), with toads from site 2 showing differences between baseline and postrestraint values (Figure 4B). Edema was observed in response to both PHA and SAL injections (Table 2); nevertheless, PHA edema was higher than SAL edema (Table 2). Additionally, the swelling differed for PHA treatment at site 2 between the times postinjection $(p=0.043)$, showing greater edema $12 \mathrm{~h}$ post-injection when compared with 18 h (Figure 4C). Interestingly, toads from site 3 showed the maximum swelling after PHA injection (Figure 4D; $p=0.033$ ).

\section{DiscuSsion}

Toads from all sites showed a broad response pattern after a restraint protocol, displaying a general increase in physiological stress indicators, which include CORT levels and $\mathrm{N}: \mathrm{L}$ ratio; and a decrease in BKA, a variable related to immune response. Regarding site contamination, individuals of the least contaminated site (site 3) showed larger spleen relative mass (immune organ), larger maximum swelling after the PHA challenge, and smaller kidneys relative mass (depurating organ). 
Contrary to our predictions, the sediment trace elements concentration at Doce River was lower at the city closer to the dam rupture (Ipatinga). This result can be explained by the fact that our data collection happened more than 2 years after the dam rupture, and since the Doce is a flowing river, the waste kept moving towards the estuary region (Linhares), which is the farthest point from the dam. These same trace elements ( $\mathrm{Al}, \mathrm{Ca}, \mathrm{Cr}, \mathrm{Fe}, \mathrm{Mn}$, and $\mathrm{Zn}$ ), were found in the estuary sediment in lower concentrations 75 days after the dam rupture (Hatje et al., 2017). Considering USA scale of contamination, the trace elements $\mathrm{Cr}$ and $\mathrm{Mn}$ found in the sediment of site 2, and $\mathrm{Mn}$ found in Governador Valadares riverbanks, had concentrations above the Threshold Effect Level (TEL) (Cr: $37.3 \mathrm{mg} / \mathrm{kg}$; and Mn: $460 \mathrm{mg} / \mathrm{kg}$; Buchman, 2008). The trace elements in sediment from all sites were below threshold levels allowed in Brazilian law (CONAMA, 2009). According to Brazilian law, Al was above threshold limits in water from all sites alongside Doce River; and Fe was above threshold limits in water from all sites, except for Ipatinga lagoon and site 3 (CONAMA, 2005). The results found for trace elements cannot be promptly connected to the dam rupture occurred two years ago, instead, it might be related with that the State of Minas Gerais is an ore mining activity pole for containing naturally high concentrations of $\mathrm{Au}$ and $\mathrm{Fe}$ (Roeser \& Roeser, 2016; Silva, 1995).

Concerning trace elements found in the liver, the PCA analysis clustered them into 2 components. The first component $(\mathrm{C} 1)$, associated $\mathrm{Mg}$ and $\mathrm{Zn}$ and, the second $(\mathrm{C} 2)$ linked $\mathrm{Cu}$ and $\mathrm{Fe}$ together. All these trace elements are somehow involved with regulation of immune function, but the $\mathrm{C} 2$ elements and $\mathrm{Zn}$ can also be linked to metabolic functions (Beck et al., 2014; Collins et al., 2010; Jankun et al., 2013; Prasad, 2008.; Wintergerst \& Hornig, 2007; Xu et al., 2018). Toads with larger spleen relative mass were those with greater liver concentrations of $\mathrm{Zn}$ (site 3). $\mathrm{Zn}$ is an important element linked to 
immunomodulation with several studies associating $\mathrm{Zn}$ deficiency to suppression of the immune system; and spleen is a lymphoid organ responsible for a systemic immune response (Prasad, 2008; Priyadarshani et al., 2015). Therefore, larger spleen might be associated with better innate immune response found in toads from site 3 (higher maximum swelling after PHA challenge, Figure 4C) compared with sites 1 and 2. The trace elements of $\mathrm{C} 1$ were inversely correlated with livers relative mass, the main metabolic organ. Considering that the liver is the largest organ of clearance in the organism, this may indicate that this organ is undergoing hypertrophy in an attempt to metabolize and excrete a larger amount of those metals. More studies must be carried out, on trace elements in metabolic and immune pathways, to determine the effects of longterm exposure to them, including histological measurements.

Toads from different sites showed similar CORT baseline levels and increased CORT levels in response to $1 \mathrm{~h}$ restraint stress protocol, ranging from 15 to 19 times compared with the baseline levels. Similarly, birds (Ficedula hypoleuca) collected in sites contaminated with trace elements did not differ in basal CORT levels from those collected in reference sites (Eeva et al., 2005). Otherwise, toads (Anaxyrus terrestris) and birds (Tachycineta bicolor) living in contaminated sites showed higher basal CORT levels when compared with reference sites (Beck et al., 2014; Hopkins et al., 1997). Moreover, Beck and collaborators (2014) found that birds from a reference site showed a greater increase in CORT levels post-restraint when compared with individuals living in contaminated sites but related these differences with ecological variation instead of contamination levels among sites (Beck et al., 2014). These contrasting results might be explained, at least partially, by adjustments in CORT synthesis pathway after long-term exposure to contaminants. These adjustments might lead to a reduction of initial differences in CORT levels as contaminants exposure time increases (Eeva et al., 2005). 
Considering that toads were collected 2 years after the dam rupture, the absence of differences in basal and post-restraint CORT levels among sites might result from adjustments in CORT synthesis pathway.

Site 2 had the most contaminated sediment alongside Doce River and, contrary to our prediction, toads from this site showed higher baseline and post-restraint $\mathrm{T}$ levels. Additionally, toads from site 1 exhibited decreased post-restraint T levels when compared with baseline conditions. Assis and collaborators (2019) found that $24 \mathrm{~h}$ restraint with and without movement restriction decreased T plasma levels, but they could not correlate this to increased CORT plasma levels (Assis et al., 2019). These results indicate that decreased $\mathrm{T}$ levels in response to stressful situations are a complex response that needs further studies. Hopkins and collaborators (1997) also found higher T levels in toads living in contaminated sites when compared with reference sites. According to these authors, this pattern could be due to the dysregulation of the steroid production pathway caused by contamination (Hopkins et al., 1997).

Toads from sites 1 and 2 presented similar baseline and post-restrained N:L ratio values. Otherwise, toads from the least contaminated site (site 3), showed increased postrestraint $\mathrm{N}: \mathrm{L}$ ratio when compared with baseline levels. The $\mathrm{N}: \mathrm{L}$ ratio has been proved to be an important indicator of stress response (Davis et al., 2008; Davis \& Maney, 2018). Even though variation in CORT and N:L ratio are not often associated following a stressor (Assis et al., 2019; Titon et al., 2019), increased N:L ratio after restraint has been an important indicator of stress intensity in Rhinella toads, including $R$. diptycha (Assis et al., 2019). Although toads from different sites showed similar baseline and post-restraint CORT in the present study, the immune redistribution observed in toads from site 3 suggests that those animals managed to mount a response to an additional acute stressor. Increased neutrophil recruitment may be relevant for protection during the stress response 
since neutrophils are the first line of defense in blood against pathogens that can reach the circulation (Davis et al., 2008; Davis; Maney, 2018; Dhabhar, 2002). Therefore, the absence of changes in N:L ratio after restraint in toads from sites 1 and 2 might indicate that high levels of environmental contamination can affect the individual's response to further stressors.

Regarding immunity, toads from the three sites presented a similar general response pattern with a reduction of BKA in response to an acute stressor and an edema in response to a PHA injection. Similar results were found in studies with birds (Tachycineta bicolor and Somateria mollissima borealis), alligators (Alligator mississippiensis) and tortoises (Kinosternon subrubrum) comparing contaminated by trace elements and reference sites (Beck et al., 2014; Cochran et al., 2018; Finger et al., 2016; Wayland et al., 2002). This could indicate that contamination by trace elements do not interfere strongly in the ability of those animals to mount an immune response against foreign pathogens. Interestingly, we observed that individuals from all sites showed postrestraint increase CORT and decreased BKA. This result corroborates previous observations by other authors, which show that animals tend to decrease BKA after acute restraint stress (Assis et al., 2019; Matson et al., 2006). Meanwhile, we found no correlation between the parameters related with stress response with those related with immunity, which indicates the decreased BKA following restraint might not be directly associated with increased CORT plasma levels, corroborating results from previous studies with anurans (Assis et al., 2015; Assis et al., 2019; Graham et al., 2012). We also need to consider that single temporal samplings, as conducted in this study, might blurs relationships that would be evident when considering different temporal dynamics between variables. 
All toads were sensitive to PHA injections, responding with edema. However, toads from the less contaminated site presented a greater edema intensity in response to a PHA injection, indicating that environmental contamination may impact the intensity of cellular immune response. Similar to our results, other studies showed that individuals living in contaminated sites or administrated with trace elements also respond to PHA injection but did not find correlation of trace elements accumulated in blood, kidney, and liver with swelling intensity (Beck et al., 2014; Finger et al., 2016). Our results together are pointing out that environmental contamination is driving physiological and morphological differences among the areas, with toads from the less contaminated site having better immunity. Trade-offs between the immune response and other functions under situations of limited energy resources have been described in the literature (Romero; Wingfield, 2015). While studies have shown individuals under energetic expenditure investing in immune response over reproductive effort (Cutrera et al., 2010; Martin et al., 2003), decreased immune response has been observed under highly energetic demanding activities, such as sustained locomotion (Brown \& Shine, 2014). Thus, animals investing heavily in the clearance of trace elements may have fewer resources for immune response, leading to a pattern of a compromised inflammatory response in populations under long-term exposure to contamination by trace elements. Additional study sites and immune parameters might be investigated in order to clarify this matter.

\section{Conclusion}

Thereby, the findings of this study indicate the presence of trace elements in all studied sites. Moreover, individuals from the least contaminated site (site 3) were more responsive to an acute stressor (restraint) by increasing the $\mathrm{N}: \mathrm{L}$ ratio and displaying a stronger immune response with the higher maximum swelling after a PHA challenge, 
larger spleens and smaller kidneys. Thus, our results show that as the contamination by trace elements increases in the environment the susceptibility to immunosuppression increases as well. Studies including additional replicate environmental systems and phenotypic parameters such as histology of immune and depurating organs; cytokine analyses; and the quantification of heavy metals, such as mercury and arsenic, could contribute to clarify the interactions among trace elements bioaccumulation, stress and immune response in toads.

\section{ACKNOWLEDGMENTS}

This work was funded by Coordenação de Aperfeiçoamento de Pessoal de Nível Superior (CAPES) (institutional quota); and Fundação de Amparo à Pesquisa do Estado de São Paulo (FAPESP) (grant number: 2014/16320-7). F.R. Gomes is a research fellow from the Conselho Nacional de Desenvolvimento Científico e Tecnológico (CNPq) \#302308/2016-4. The authors thank the technicians Márcio P. Lima and Raphaela C.

Ribeiro for field support; Sheila C. Silva and Rayssa L. Cardoso for support in biochemistry analyses; and Prof. Jorge A. S. Tenório and the lab technician, Ana C. F. Dalsin, for support on trace elements analyses.

\section{REFERENCES}

APHA, A. (1998). Standard methods for the examination of water and wastewater, American Public Health Association. Inc., Washington. DC. https://ajph.aphapublications.org/doi/pdf/10.2105/AJPH.56.3.387

Arantes, F. P., Savassi, L. A., Santos, H. B., Gomes, M. V. T., \& Bazzoli, N. (2016). Bioaccumulation of mercury, cadmium, zinc, chromium, and lead in muscle, liver, and spleen tissues of a large commercially valuable catfish species from Brazil. Anais Da Academia Brasileira de Ciencias, 88(1), 137-147. https://doi.org/10.1590/0001-3765201620140434

Assis, V. R. de, Titon, S. C. M., Barsotti, A. M. G., Spira, B., \& Gomes, F. R. (2013). Antimicrobial Capacity of Plasma from Anurans of the Atlantic Forest. South American Journal of Herpetology, 8(3), 155-160. https://doi.org/10.2994/sajh-d13-00007.1

Assis, V. R., Titon, S. C. M., Barsotti, A. M. G., Titon, B., \& Gomes, F. R. (2015). Effects of acute restraint stress, prolonged captivity stress and transdermal corticosterone application on immunocompetence and plasma levels of 
corticosterone on the cururu toad (Rhinella icterica). PLoS ONE, 10(4), 1-21. https://doi.org/10.1371/journal.pone.0121005

Assis, V. R., Titon, S. C. M., Queiroz-Hazarbassanov, N. G. T., Massoco, C. O., \& Gomes, F. R. (2017). Corticosterone transdermal application in toads (Rhinella icterica): Effects on cellular and humoral immunity and steroid plasma levels. Journal of Experimental Zoology Part A: Ecological and Integrative Physiology, 327(4), 200-213. https://doi.org/10.1002/jez.2093

Assis, V. R., Titon, S. C. M., \& Gomes, F. R. (2019). Acute stress, steroid plasma levels, and innate immunity in Brazilian toads. General and Comparative Endocrinology, 273(May), 86-97. https://doi.org/10.1016/j.ygcen.2018.05.008

Barriga, C., Martín, M. I., Tabla, R., Ortega, E., \& Rodríguez, A. B. (2001). Circadian rhythm of melatonin, corticosterone and phagocytosis: effect of stress. Journal of pineal research, 30(3), 180-187. https://doi.org/10.1034/j.1600079X.2001.300307.x

Beck, M. L., Hopkins, W. A., Hallagan, J. J., Jackson, B. P., \& Hawley, D. M. (2014). Exposure to residual concentrations of elements from a remediated coal fly ash spill does not adversely influence stress and immune responses of nestling tree swallows. Conservation physiology, 2(1), https://doi.org/10.1093/conphys/cou018.

Bottino, F., Milan, J. A. M., Cunha-Santino, M. B., \& Bianchini, I. (2017). Influence of the residue from an iron mining dam in the growth of two macrophyte species. Chemosphere, 186, 488-494. https://doi.org/10.1016/j.chemosphere.2017.08.030

Brasil, Ministério do Meio Ambiente, C. N. do M. A. (CONAMA). (2005). Resolução No. 357 de 18 de março de 2005 do Ministério do Meio Ambiente, Conselho Nacional do Meio Ambiente (CONAMA). Diário Oficial Da União, Brasília, Brasil, (053), 58-63. https://doi.org/nº 053, de 18/03/2005

Brasil, Ministério do Meio Ambiente, C. N. do M. A. (CONAMA). (2009). Resolução No. 420 de 30 de dezembro de 2009 do Ministério do Meio Ambiente, Conselho Nacional do Meio Ambiente (CONAMA). Diário Oficial Da União, Brasília, Brasil, (249), 81-84.

Brown, G. P., Shilton, C. M., \& Shine, R. (2011). Measuring amphibian immunocompetence: Validation of the phytohemagglutinin skin-swelling assay in the cane toad, Rhinella marina. Methods in Ecology and Evolution, 2(4), 341-348. https://doi.org/10.1111/j.2041-210X.2011.00090.x

Brown, G. P., \& Shine, R. (2014). Immune response varies with rate of dispersal in invasive cane toads (Rhinella marina). PLoS One, 9(6), e99734. https://doi.org/10.1371/journal.pone.0099734

Buchman, M. F. (2008). Screening Quick Reference Tables (SQuiRTs).

Campbell, T. W. (2006). Hematologia de anfíbios. Hematologia e Bioquímica Clínica Veterinária. Roca, 291-300.

Carvalho, C. S., Utsunomiya, H. S. M., Pasquoto, T., Lima, R., Costa, M. J., \& Fernandes, M. N. (2017). Blood cell responses and metallothionein in the liver, kidney and muscles of bullfrog tadpoles, Lithobates catesbeianus, following exposure to different metals. Environmental Pollution, 221(December), 445-452. https://doi.org/10.1016/j.envpol.2016.12.012

Cochran, J. P., Haskins, D. L., Eady, N. A., Hamilton, M. T., Pilgrim, M. A., \& Tuberville, T. D. (2018). Coal combustion residues and their effects on trace element accumulation and health indices of eastern mud turtles (Kinosternon subrubrum). Environmental Pollution, 243, 346-353.

https://doi.org/10.1016/j.envpol.2018.08.035

Collins, J. F., Prohaska, J. R., \& Knutson, M. D. (2010). Metabolic crossroads of iron 
and copper. Nutrition reviews, 68(3), 133-147. https://doi.org/10.1111/j.17534887.2010.00271.x

Cutrera, A. P., Zenuto, R. R., Luna, F., \& Antenucci, C. D. (2010). Mounting a specific immune response increases energy expenditure of the subterranean rodent Ctenomys talarum (tuco-tuco): implications for intraspecific and interspecific variation in immunological traits. Journal of Experimental Biology, 213(5), 715724. https://doi.org/10.1242/jeb.037887

Davis, A. K., Maney, D. L., \& Maerz, J. C. (2008). The use of leukocyte profiles to measure stress in vertebrates: A review for ecologists. Functional Ecology, 22(5), 760-772. https://doi.org/10.1111/j.1365-2435.2008.01467.x

Davis, Andrew K., \& Maney, D. L. (2018). The use of glucocorticoid hormones or leucocyte profiles to measure stress in vertebrates: What's the difference? Methods in Ecology and Evolution, 9(6), 1556-1568. https://doi.org/10.1111/2041210X.13020

Dhabhar, F. S., \& McEwen, B. S. (1997). Acute stress enhances while chronic stress suppresses cell-mediated immunityin vivo: A potential role for leukocyte trafficking. Brain, behavior, and immunity, 11(4), 286-306. https://doi.org/10.1006/brbi.1997.0508

Dhabhar, F. S. (2002). A hassle a day may keep the doctor away: stress and the augmentation of immune function. Integrative and Comparative Biology, 42(3), 556-564. https://doi.org/10.1093/icb/42.3.556

Dhabhar, F. S. (2014). Effects of stress on immune function : the good, the bad, and the beautiful.Immunologic research, 58(2-3), 193-210. https://doi.org/10.1007/s12026-014-8517-0

Eeva, T., Langefors, Å., Hasselquist, D., Ilmonen, P., Tummeleht, L., \& Nikinmaa, M. (2005). Pollution related effects on immune function and stress in a free-living population of pied flycatcher Ficedula hypoleuca . Journal of Avian Biology, 36(5), 405-412. https://doi.org/10.1111/j.0908-8857.2005.03449.x

Falso, P. G., Noble, C. A., Diaz, J. M., \& Hayes, T. B. (2015). The effect of long-term corticosterone treatment on blood cell differentials and function in laboratory and wild-caught amphibian models. General and Comparative Endocrinology, 212, 73-83. https://doi.org/10.1016/j.ygcen.2015.01.003

Finger, J. W., Hamilton, M. T., Metts, B. S., Glenn, T. C., \& Tuberville, T. D. (2016). Chronic Ingestion of Coal Fly-Ash Contaminated Prey and Its Effects on Health and Immune Parameters in Juvenile American Alligators (Alligator mississippiensis). Archives of Environmental Contamination and Toxicology, 71(3), 347-358. https://doi.org/10.1007/s00244-016-0301-9

Gomes, L. E. de O., Correa, L. B., Sá, F., Neto, R. R., \& Bernardino, A. F. (2017). The impacts of the Samarco mine tailing spill on the Rio Doce estuary, Eastern Brazil. Marine Pollution Bulletin, 120(1-2), 28-36. https://doi.org/10.1016/j.marpolbul.2017.04.056

Graham, S. P., Kelehear, C., Brown, G. P., \& Shine, R. (2012). Corticosterone-immune interactions during captive stress in invading Australian cane toads (Rhinella marina). Hormones and Behavior, 62(2), 146-153. https://doi.org/10.1016/j.yhbeh.2012.06.001

Guo, R., Zhang, W., Yang, Y., Ding, J., Yang, W., \& Zhang, Y. (2018). Variation of fitness and reproductive strategy in male Bufo raddei under environmental heavy metal pollution. Ecotoxicology and Environmental Safety, 164(June), 253-260. https://doi.org/10.1016/j.ecoenv.2018.08.035

Haskins, D. L., Hamilton, M. T., Stacy, N. I., Finger, J. W., \& Tuberville, T. D. (2017). 
Effects of selenium exposure on the hematology, innate immunity, and metabolic rate of yellow-bellied sliders (Trachemys scripta scripta). Ecotoxicology, 26(8), 1134-1146. https://doi.org/10.1007/s10646-017-1839-7

Hatje, V., Pedreira, R. M. A., De Rezende, C. E., Schettini, C. A. F., De Souza, G. C., Marin, D. C., \& Hackspacher, P. C. (2017). The environmental impacts of one of the largest tailing dam failures worldwide. Scientific Reports, 7(1), 1-13. https://doi.org/10.1038/s41598-017-11143-x

Hopkins, W. A., Mendonça, M. T., \& Congdon, J. D. (1997). Increased circulating levels of testosterone and corticosterone in southern toads, Bufo terrestris, exposed to coal combustion waste. General and Comparative Endocrinology, 108(2), 237246. https://doi.org/10.1006/gcen.1997.6969

Huang, M. Y., Duan, R. Y., \& Ji, X. (2014). Chronic effects of environmentallyrelevant concentrations of lead in Pelophylax nigromaculata tadpoles: Threshold dose and adverse effects. Ecotoxicology and Environmental Safety, 104(1), 310316. https://doi.org/10.1016/j.ecoenv.2014.03.027

Jankun, J., Skrzypczak-jankun, E. W. A., \& Lipinski, B. A. W. (2013). Complex function of magnesium in blood clot formation and lysis. Central European Journal of Immunology, 38(2), 149-153. https://doi.org/10.5114/ceji.2013.35203

Jayawardena, U. A., Ratnasooriya, W. D., Wickramasinghe, D. D., \& Udagama, P. V. (2016). Heavy metal mediated innate immune responses of the Indian green frog, Euphlyctis hexadactylus (Anura: Ranidae): Cellular profiles and associated Th1 skewed cytokine response. Science of the Total Environment, 566, 1194-1204. https://doi.org/10.1016/j.scitotenv.2016.05.171

Lavilla, E. O., \& Brusquetti, F. (2018). On the identity of Bufo diptychus Cope, 1862 (anura: Bufonidae). https://doi.org/10.11646/zootaxa.4442.1.9

Linzey, D. W., Burroughs, J., Hudson, L., Marini, M., Robertson, J., Bacon, J. P., ... Nagarkatti, P. S. (2003). Role of environmental pollutants on immune functions, parasitic infections and limb malformations in marine toads and whistling frogs from Bermuda. International Journal of Environmental Health Research, 13(2), 125-148. https://doi.org/10.1080/0960312031000098053

Machado, I. F., \& Silvia, S. F. (2001). 500 years of mining in Brazil: A brief review. Resources Policy, 27(1), 9-24. https://doi.org/10.1016/S0301-4207(01)00004-6

Martin, L. B., Scheuerlein, A., \& Wikelski, M. (2003). Immune activity elevates energy expenditure of house sparrows: a link between direct and indirect costs?. Proceedings of the Royal Society of London. Series B: Biological Sciences, 270 (1511), 153-158. https://doi.org/10.1098/rspb.2002.2185

Matson, K. D., Tieleman, B. I., \& Klasing, K. C. (2006). Capture Stress and the Bactericidal Competence of Blood and Plasma in Five Species of Tropical Birds. Physiological and Biochemical Zoology, 79(3), 556-564. https://doi.org/10.1086/501057

Mendonça, M. T., Chernetsky, S. D., Nester, K. E., \& Gardner, G. L. (1996). Effects of gonadal sex steroids on sexual behavior in the big brown bat, Eptesicus fuscus, upon arousal from hibernation. Hormones and Behavior, 30(2), 153-161. https://doi.org/10.1006/hbeh.1996.0019

Norris, D. O., Felt, S. B., Woodling, J. D., \& Dores, R. M. (1997). Immunocytochemical and histological differences in the interrenal axis of feral brown trout, Salmo trutta, in metal-contaminated waters. General and Comparative Endocrinology, 108(3), 343-351. https://doi.org/10.1006/gcen.1997.7000

Otero, M. A., Pollo, F. E., Grenat, P. R., Salas, N. E., \& Martino, A. L. (2018). 
Differential effects on life history traits and body size of two anuran species inhabiting an environment related to fluorite mine. Ecological Indicators, 93(April), 36-44. https://doi.org/10.1016/j.ecolind.2018.04.065

Pramuk, J. B. (2006). Phylogeny of south American Bufo (Anura: Bufonidae) inferred from combined evidence. Zoological journal of the Linnean society, 146(3), 407452.Prasad, A. S. (n.d.). Zinc in Human Health : Effect of Zinc on Immune Cells. 2, 5-9. https://doi.org/10.1111/j.1096-3642.2006.00212.x

Prasad, A. S. (2008). Zinc in human health: effect of zinc on immune cells. Molecular medicine, 14(5-6), 353-357. https://doi.org/10.2119/2008-00033.Prasad

Priyadarshani, S., Madhushani, W. A. N., Jayawardena, U. A., Wickramasinghe, D. D., \& Udagama, P. V. (2015). Heavy metal mediated immunomodulation of the Indian green frog, Euphlyctis hexadactylus (Anura: Ranidae) in urban wetlands. Ecotoxicology and Environmental Safety, 116, 40-49. https://doi.org/10.1016/j.ecoenv.2015.02.037

Prokić, M. D., Borković-Mitić, S. S., Krizmanić, I. I., Mutić, J. J., Vukojević, V., Nasia, M., ... Saičić, Z. S. (2016a). Antioxidative responses of the tissues of two wild populations of Pelophylax kl. esculentus frogs to heavy metal pollution. Ecotoxicology and Environmental Safety, 128, 21-29. https://doi.org/10.1016/j.ecoenv.2016.02.005

Prokić, M. D., Borković-Mitić, S. S., Krizmanić, I. I., Mutić, J. J., Trifković, J., Gavrić, J. P., ... Saičić, Z. S. (2016b). Bioaccumulation and effects of metals on oxidative stress and neurotoxicity parameters in the frogs from the Pelophylax esculentus complex. Ecotoxicology, 25(8), 1531-1542. https://doi.org/10.1007/s10646-0161707-x

Roeser, H. M. P., \& Roeser, P. A. (2016). O Quadrilátero Ferrífero - Mg, Brasil: Aspectos Sobre Sua História, Seus Recursos Minerais E Problemas Ambientais Relacionados. Geonomos, 18(1), 33-37. https://doi.org/10.18285/geonomos.v18i1.67

Romero, L. M., \& Reed, J. M. (2005). Collecting baseline corticosterone samples in the field: is under 3 min good enough?. Comparative Biochemistry and Physiology Part A: Molecular \& Integrative Physiology, 140(1), 73-79. https://doi.org/10.1016/j.cbpb.2004.11.004

Romero, L. M., \& Wingfield, J. C. (2015). Tempests, poxes, predators, and people: stress in wild animals and how they cope. Oxford University Press. DOI:10.1093/acprof:oso/9780195366693.001.0001

Sapolsky, R. M., Romero, L. M., \& Munck, A. U. (2000). How Do Glucocorticoids Influence Stress Responses? Preparative Actions. Endocrine Reviews, 21(1), 5589.

Segura, F. R., Nunes, E. A., Paniz, F. P., Paulelli, A. C. C., Rodrigues, G. B., Braga, G. Ú. L., ... Batista, B. L. (2016). Potential risks of the residue from Samarco's mine dam burst (Bento Rodrigues, Brazil). Environmental Pollution, 218, 813-825. https://doi.org/10.1016/j.envpol.2016.08.005

Silva, O. P. (1995). A mineração em minas gerais: passado, presente e futuro. Revista Geonomos, 3(1). https://doi.org/10.18285/geonomos.v3i1.217

Sparling, D. W., Linder, G., Bishop, C. A., \& Krest, S. (2010). Ecotoxicology of amphibians and reptiles. Pensacola, FL: Society of Environmental Toxicology and Chemistry (SETAC). CRC Press. p. 15-71.

Titon, S. C. M., Assis, V. R., Titon, B., Barsotti, A. M. G., Flanagan, S. P., \& Gomes, F. R. (2016). Calling rate, corticosterone plasma levels and immunocompetence of Hypsiboas albopunctatus. Comparative Biochemistry and Physiology-Part A : 
Molecular and Integrative Physiology, 201, 53-60.

https://doi.org/10.1016/j.cbpa.2016.06.023

Titon, S. C. M., Assis, V. R., Titon Junior, B., Cassettari, B. de O., Fernandes, P. A. C. M., \& Gomes, F. R. (2017). Captivity effects on immune response and steroid plasma levels of a Brazilian toad (Rhinella schneideri). Journal of Experimental Zoology Part A: Ecological and Integrative Physiology, 327(2-3), 127-138. https://doi.org/10.1002/jez.2078

Titon, S. C. M., Titon Jr, B., Barsotti, A. M. G., Gomes, F. R., \& Assis, V. R. (2019). Time-related immunomodulation by stressors and corticosterone transdermal application in toads. PloS one, 14(9). https://doi.org/10.1371/journal.pone.0222856

Wayland, M., Gilchrist, H. G., Marchant, T., Keating, J., \& Smits, J. E. (2002). Immune function, stress response, and body condition in arctic-breeding common eiders in relation to cadmium, mercury, and selenium concentrations. Environmental Research, 90(1), 47-60. https://doi.org/10.1006/enrs.2002.4384

Wingfield, J. C. (2013). The comparative biology of environmental stress: Behavioural endocrinology and variation in ability to cope with novel, changing environments. Animal Behaviour, 85(5), 1127-1133. https://doi.org/10.1016/j.anbehav.2013.02.018

Wintergerst, E. S., Maggini, S., \& Hornig, D. H. (2007). Contribution of selected vitamins and trace elements to immune function. Annals of Nutrition and Metabolism, 51(4), 301-323. https://doi.org/10.1159/000107673

Wright, K. M. (2001). Amphibian hematology. Amphibian medicine and captive husbandry, 129, 146.

Xu, H., Zhang, X., Li, H., Li, C., Huo, X. J., Hou, L. P., \& Gong, Z. (2018). Immune response induced by major environmental pollutants through altering neutrophils in zebrafish larvae. Aquatic Toxicology, 201(May), 99-108. https://doi.org/10.1016/j.aquatox.2018.06.002

Yu, S., Halbrook, R. S., Sparling, D. W., \& Colombo, R. (2011). Metal accumulation and evaluation of effects in a freshwater turtle. Ecotoxicology, 20(8), 1801-1812. https://doi.org/10.1007/s10646-011-0716-Z

Zhang, W., Guo, R., Ai, S., Yang, Y., Ding, J., \& Zhang, Y. (2018). Long-term heavy metal pollution varied female reproduction investment in free-living anura, Bufo raddei. Ecotoxicology and Environmental Safety, 159(May), 136-142. https://doi.org/10.1016/j.ecoenv.2018.05.001

Zhelev, Z. M., Popgeorgiev, G. S., \& Mehterov, N. H. (2015). Changes in the hepatosomatic index and condition factor in the populations of Pelophylax ridibundus (Amphibia: Ranidae) from anthropogenically polluted biotopes in Southern Bulgaria. Bulgarian Journal of Agricultural Science, 21, 534-539. 


\section{FigURES AND TABLES}

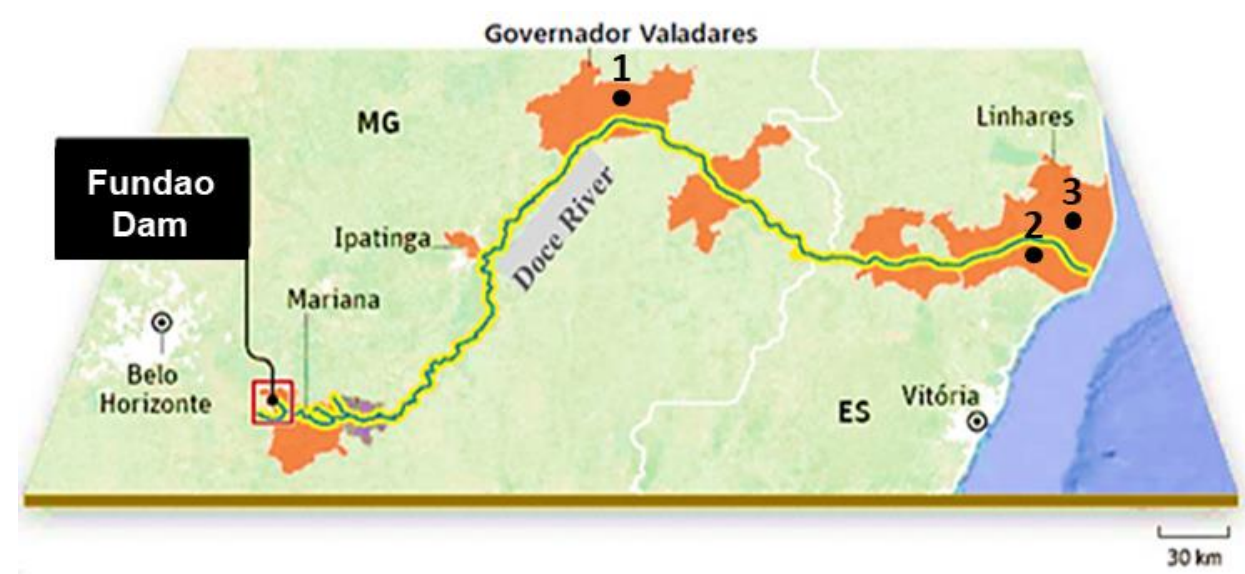

Figure 1: Map of the collection sites, with the perspective of where the dam rupture occurred. The first city by the River is Mariana, which was dam busted. Following the Doce River, there is Ipatinga (MG) $194 \mathrm{~km}$ from the dam rupture; Governador Valadares (MG) $287 \mathrm{~km}$; and Linhares (ES) $549 \mathrm{~km}$ from the dam rupture (near the estuary). Source: Modified from Folha de Sao Paulo. The numbers 1,2 and 3 means the animal's collection sites. 

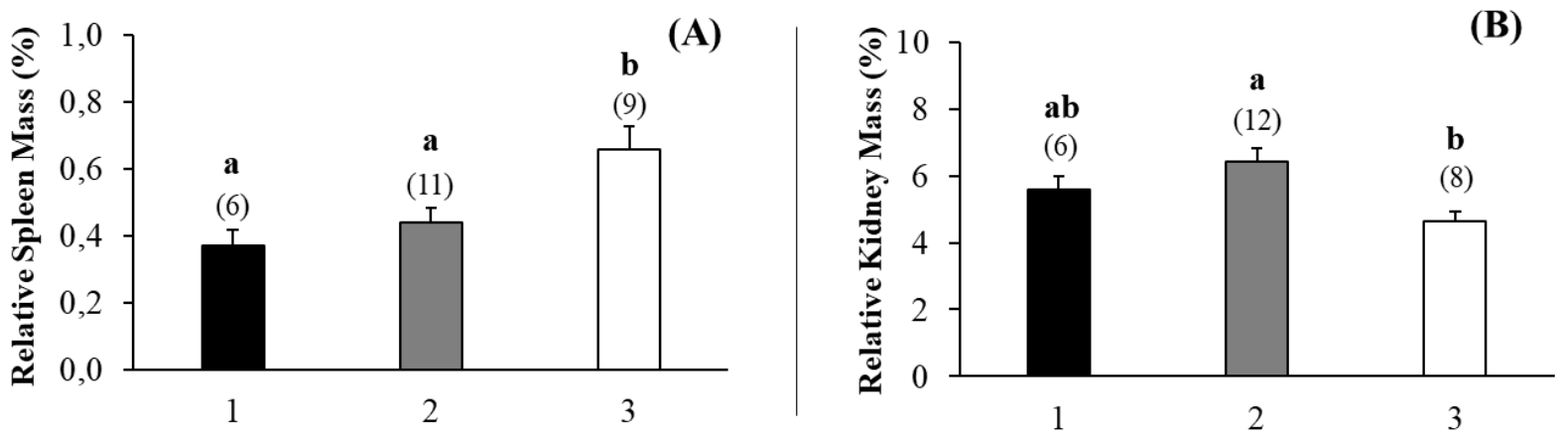

Figure 2: Organs relative mass of Rhinella diptycha among three different collection sites. (A) Relative spleen mass; (B) Relative kidney mass. The symbol (\#) represents the statistical difference between the sites by an ANOVA after Bonferroni correction $(p \leq 0.05)$. The numbers in parenthesis represent the number of individuals used on the test. The bars represent the means \pm standard error. Collection sites: 1: Governador Valadares (MG) - 29km away from the Doce River; 2: Linhares (ES) - Doce Riverbanks; and 3: Linhares (ES) - $17 \mathrm{~km}$ away from the Doce River. 
(A)
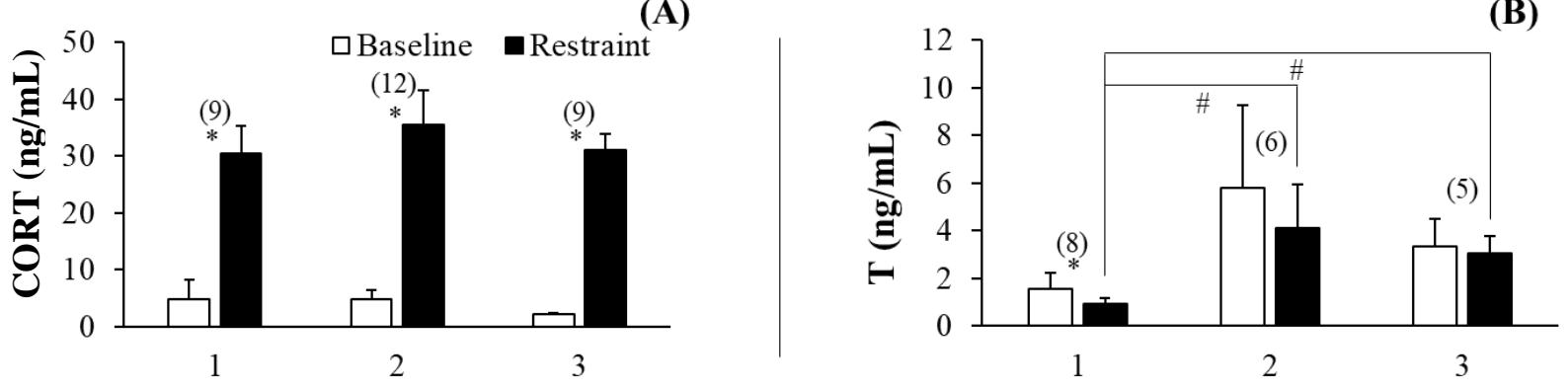

Figure 3: Hormone plasma levels of Rhinella diptycha among three different collection sites. (A) Corticosterone (CORT) plasma levels. (B) Testosterone (T) plasma levels. Asterisk (*) represents the statistical difference between baseline and post-restraint levels within each specific site by an ANOVA after Bonferroni correction $(p \leq 0.05)$. The symbol (\#) represents the statistical difference between the sites by an ANOVA after Bonferroni correction $(p \leq 0.05)$. The numbers in parenthesis represent the number of individuals used on the test. The bars represent the means \pm standard error. Collection sites: 1: Governador Valadares (MG) - 29km away from the Doce River; 2: Linhares (ES) - Doce Riverbanks; and 3: Linhares (ES) - 17km away from the Doce River. 

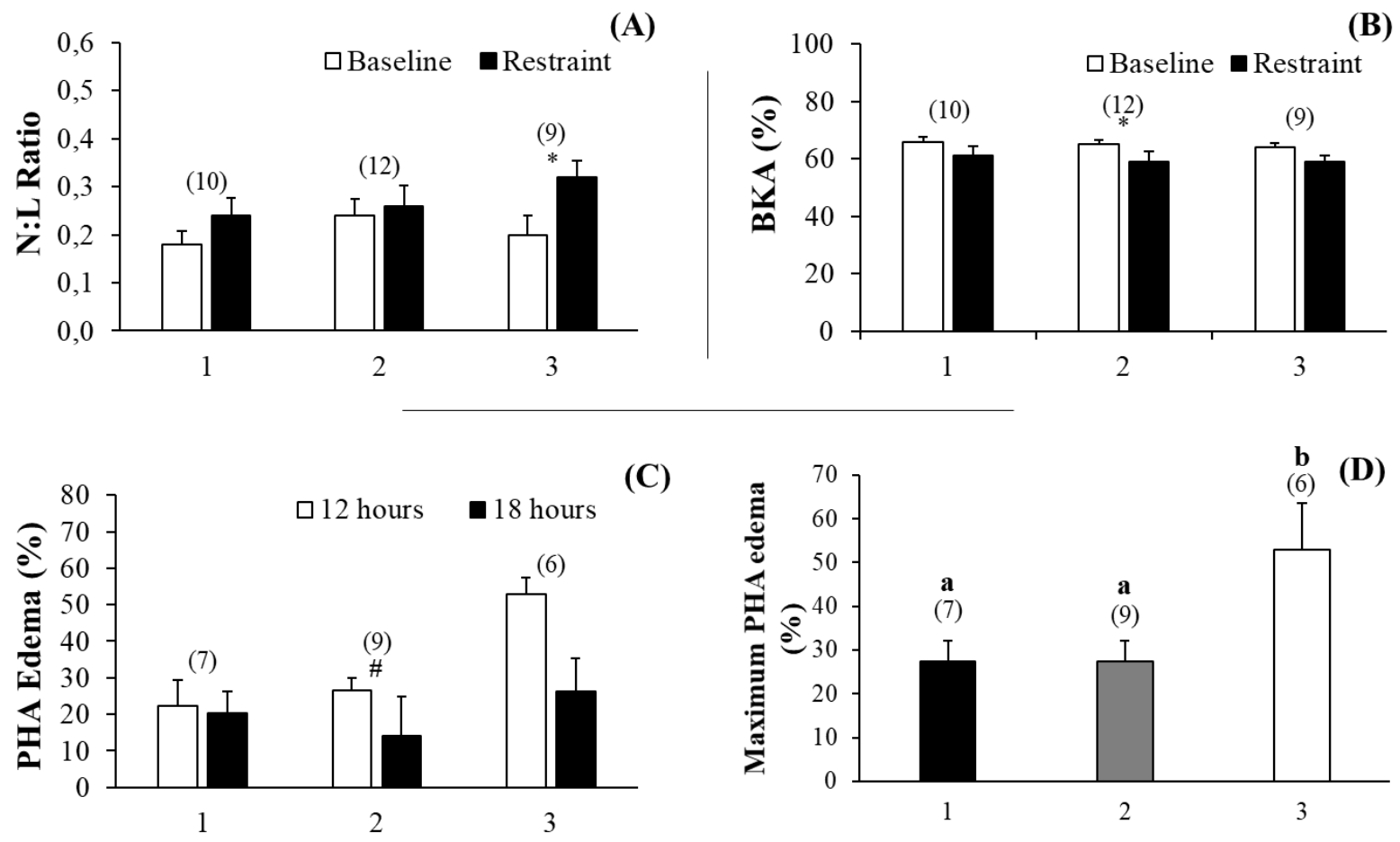

Figure 4: Immunological parameters in Rhinella diptycha among three different collection sites. (A) Neutrophil: lymphocyte ratio (N:L). (B) Bacterial killing capacity (BKA). (C) Relative edema [calculated by the measurements post-injection minus the measurement before injection times $100(12-0$ or $18-0 * 100)]$ of the animals' paw after a PHA injection. (D) Maximum edema of the animals' paw after a PHA injection. Asterisk $(*)$ represents the statistical difference between baseline and post-restraint levels within each specific site by an ANOVA after Bonferroni correction $(p \leq 0.05)$. The symbol (\#) represents the statistical difference between time post-injection within each specific site by an ANOVA after Bonferroni correction $(p \leq 0.05)$. The letters $\mathrm{a}$ and $\mathrm{b}$ represent the statistical difference of maximum swelling among three different sites by an ANOVA after Bonferroni correction $(p \leq 0.05)$. The numbers in parenthesis represent the number of individuals used on the test. The bars represent the means \pm standard error. Collection sites: 1: Governador Valadares (MG) - 29km away from the Doce River; 2: Linhares (ES) - Doce Riverbanks; and 3: Linhares (ES) - $17 \mathrm{~km}$ away from the Doce River. 
Table 1: Trace elements concentration in water and sediment.

\begin{tabular}{|c|c|c|c|c|c|c|c|}
\hline & \multirow[b]{2}{*}{ Variables } & \multicolumn{3}{|c|}{ No animals collected } & \multicolumn{3}{|c|}{ Animals' collected } \\
\hline & & $\begin{array}{l}\text { Ipatinga } \\
\text { River }\end{array}$ & $\begin{array}{l}\text { Ipatinga } \\
\text { Lagoon }\end{array}$ & $\begin{array}{c}\text { Governador } \\
\text { Valadares } \\
\text { River } \\
\end{array}$ & Site 1 & Site 2 & Site 3 \\
\hline \multirow{7}{*}{ 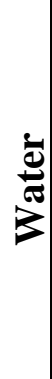 } & pH & 6.23 & 7.45 & 6.20 & 6.84 & 6.24 & 6.37 \\
\hline & DO (ppm) & 7.62 & 5.44 & 6.69 & 6.91 & 7.54 & 7.47 \\
\hline & $\operatorname{Temp}\left({ }^{\circ} \mathrm{C}\right)$ & 30.00 & 30.20 & 31.00 & 32.70 & 31.20 & 28.90 \\
\hline & $\mathbf{A l}(\mathrm{mg} / \mathrm{L})$ & 0.42 & $<1.01$ & 0.15 & 0.08 & 0.45 & $<1.01$ \\
\hline & $\mathbf{C a}(\mathrm{mg} / \mathrm{L})$ & 0.42 & 0.65 & 0.28 & 1.70 & 0.39 & 0.17 \\
\hline & $\mathbf{F e}(\mathrm{mg} / \mathrm{L})$ & 1.06 & 0.10 & 0.31 & 0.56 & 0.56 & 0.03 \\
\hline & $\mathbf{M g}(\mathrm{mg} / \mathrm{L})$ & 0.14 & 0.66 & 0.11 & 0.68 & 0.17 & 0.17 \\
\hline \multirow{7}{*}{ 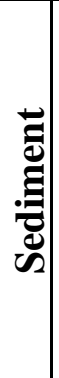 } & Al (mg/Kg) & 4468.25 & 20672.39 & 23824.18 & 28979.27 & 60826.80 & 1236.83 \\
\hline & $\mathbf{C a}(\mathrm{mg} / \mathrm{Kg})$ & 57.27 & 786.97 & 565.13 & 1089.44 & 734.65 & 20.89 \\
\hline & $\mathbf{C r}(\mathrm{mg} / \mathrm{Kg})$ & 21.72 & 27.87 & 32.50 & 29.78 & 44.13 & $<0.51$ \\
\hline & $\mathbf{F e}(\mathrm{mg} / \mathrm{Kg})$ & 14891.60 & 17428.07 & 44772.87 & 17884.65 & 47657.49 & 418.99 \\
\hline & $\mathbf{M g}(\mathrm{mg} / \mathrm{Kg})$ & 128.37 & 2921.97 & 877.86 & 1488.98 & 1992.47 & $<1.03$ \\
\hline & $\mathbf{M n}(\mathrm{mg} / \mathrm{Kg})$ & 183.80 & 386.73 & 498.65 & 125.78 & 632.98 & $<1.03$ \\
\hline & $\mathbf{Z n}(\mathrm{mg} / \mathrm{Kg})$ & 9.64 & 73.42 & 25.98 & 19.11 & 43.76 & $<1.03$ \\
\hline
\end{tabular}

The values above are reported as the raw data to each site. Abbreviations: Sites where animals' were not collected: Ipatinga River: Ipatinga city (MG) alongside Doce River; Ipatinga Lagoon: Ipatinga city (MG) by a lagoon (21 km away from the Doce River); Governador Valadares River: Governador Valadares city (MG) alongside Doce River; Sites where animals' were collected: Site 1: Governador Valadares city (MG) by a lagoon (29 km away from the Doce River); Site 2: Linhares city (ES) alongside Doce River; Site 3: Linhares city (ES) by a lagoon (17 km away from the Doce River); $\mathbf{p H}$ : potential of hydrogen DO: dissolved oxygen; Temp: temperature; Al: aluminum; Ca: calcium; Fe: iron; Mg: magnesium; Cr: chrome; Mn: manganese; Zn: zinc. The data with this symbol $(<)$ represents samples with values below the equipment calibration curve. 
Table 2: Comparison of morphological, trace elements bioaccumulation and physiological parameters among the three collection sites.

\begin{tabular}{|c|c|c|c|c|c|c|}
\hline Variables & Source & Type III SS & DF & MS & $\mathbf{F}$ & $\boldsymbol{P}$ \\
\hline \multirow{3}{*}{$\begin{array}{c}\text { Relative } \\
\text { Kidney Mass } \\
(\%)\end{array}$} & Intercept & 73.524 & 1 & 73.524 & 5448.436 & $<0.001$ \\
\hline & Site & 0.222 & 2 & 0.111 & 8.229 & 0.002 \\
\hline & Error & 0.310 & 23 & 0.013 & & \\
\hline \multirow{3}{*}{$\begin{array}{c}\text { Relative } \\
\text { Spleen Mass } \\
(\%)\end{array}$} & Intercept & 14.647 & 1 & 14.647 & 1988.098 & $<0.001$ \\
\hline & Site & 0.097 & 2 & 0.048 & 6.563 & 0.006 \\
\hline & Error & 0.169 & 23 & 0.007 & & \\
\hline \multirow{3}{*}{$\mathrm{Ca}(\mathrm{mg} / \mathrm{mL})$} & Intercept & 119.117 & 1 & 119.117 & 11617.995 & $<0.001$ \\
\hline & Site & 0.470 & 2 & 0.235 & 22.936 & $<0.001$ \\
\hline & Error & 0.246 & 24 & 0.010 & & \\
\hline \multirow{3}{*}{$\mathrm{Cu}(\mathrm{mg} / \mathrm{mL})$} & Intercept & 73.772 & 1 & 73.772 & 1018.950 & $<0.001$ \\
\hline & Site & 0.019 & 2 & 0.010 & 0.133 & 0.876 \\
\hline & Error & 1.014 & 14 & 0.072 & & \\
\hline \multirow{3}{*}{$\mathrm{Fe}(\mathrm{mg} / \mathrm{mL})$} & Intercept & 159.071 & 1 & 159.071 & 2300.822 & $<0.001$ \\
\hline & Site & 0.054 & 2 & 0.027 & 0.392 & 0.680 \\
\hline & Error & 1.798 & 26 & 0.069 & & \\
\hline \multirow{3}{*}{$\mathrm{Zn}(\mathrm{mg} / \mathrm{mL})$} & Intercept & 45.737 & 1 & 45.737 & 12027.127 & $<0.001$ \\
\hline & Site & 0.055 & 2 & 0.027 & 7.184 & 0.007 \\
\hline & Error & 0.053 & 14 & 0.004 & & \\
\hline \multirow{6}{*}{$\begin{array}{c}\text { CORT } \\
(\mathrm{ng} / \mathrm{mL})\end{array}$} & Intercept & 47.750 & 1 & 48.000 & 354.903 & $<0.001$ \\
\hline & Restraint & 18.083 & 1 & 18.083 & 196.999 & $<0.001$ \\
\hline & Restraint*Site & 0.101 & 2 & 0.051 & 0.551 & 0.583 \\
\hline & Error (restraint) & 2.478 & 27 & 0.092 & & \\
\hline & Site & 0.176 & 2 & 0.088 & 0.653 & 0.529 \\
\hline & Error & 3.633 & 27 & 0.135 & & \\
\hline \multirow{6}{*}{$\mathrm{E}(\mathrm{ng} / \mathrm{mL})$} & Intercept & 0.393 & 1 & 0.393 & 0.518 & 0.492 \\
\hline & Restraint & 0.005 & 1 & 0.005 & 0.267 & 0.619 \\
\hline & Restraint*Site & 0.008 & 2 & 0.004 & .0242 & 0.791 \\
\hline & Error (restraint) & 0.138 & 8 & 0.017 & & \\
\hline & Site & 0.967 & 2 & 0.484 & 0.638 & 0.553 \\
\hline & Error & 6.063 & 8 & 0.758 & & \\
\hline \multirow{6}{*}{$\mathrm{T}(\mathrm{ng} / \mathrm{mL})$} & Intercept & 2.962 & 1 & 2.962 & 11.463 & 0.004 \\
\hline & Restraint & 0.031 & 1 & 0.031 & 1.978 & 0.179 \\
\hline & Restraint*Site & 0.037 & 2 & 0.018 & 1.181 & 0.332 \\
\hline & Error (restraint) & 0.249 & 16 & 0.016 & & \\
\hline & Site & 2.532 & 2 & 1.266 & 4.901 & 0.022 \\
\hline & Error & 4.134 & 16 & 0.258 & & \\
\hline
\end{tabular}


Table 2 - continued

\begin{tabular}{|c|c|c|c|c|c|c|}
\hline \multirow{6}{*}{$\mathrm{N}: \mathrm{L}$} & Intercept & 22.351 & 1 & 22.351 & 1379.362 & $<0.001$ \\
\hline & Restraint & 0.042 & 1 & 0.042 & 6.897 & 0.014 \\
\hline & Restraint*Site & 0.029 & 2 & 0.014 & 2.351 & 0.114 \\
\hline & Error (restraint) & 0.171 & 28 & 0.006 & & \\
\hline & Site & 0.025 & 2 & 0.012 & 0.764 & 0.475 \\
\hline & Error & 0.454 & 28 & 0.016 & & \\
\hline \multirow{6}{*}{ BKA $(\%)$} & Intercept & 2.639 & 1 & 2.639 & 710.592 & $<0.001$ \\
\hline & Restraint & 0.029 & 1 & 0.029 & 8.637 & $\mathbf{0 . 0 0 7}$ \\
\hline & Restraint*Site & 0.001 & 2 & $<0.001$ & 0.118 & 0.889 \\
\hline & Error (restraint) & 0.093 & 28 & 0.003 & & \\
\hline & Site & 0.003 & 2 & 0.001 & 0.398 & 0.675 \\
\hline & Error & 0.104 & 28 & 0.004 & & \\
\hline \multirow{12}{*}{$\begin{array}{l}\text { PHA and } \\
\text { SAL }(\%)\end{array}$} & Intercept & 166.447 & 1 & 166.447 & 32.606 & $<0.001$ \\
\hline & Treatment & 141.403 & 1 & 141.403 & 77.181 & $<0.001$ \\
\hline & Treatment*Site & 3.552 & 2 & 1.776 & 0.969 & 0.397 \\
\hline & Error (treatment) & 34.810 & 19 & 1.832 & & \\
\hline & Time & 9.451 & 1 & 9.451 & 3.903 & 0.063 \\
\hline & Time*Site & 5.113 & 2 & 2.556 & 1.056 & 0.368 \\
\hline & Error (time) & 46.011 & 19 & 2.422 & & \\
\hline & Treatment*Time & 0.482 & 1 & 0.482 & 0.401 & 0.534 \\
\hline & Treatment*Time*Site & 1.079 & 2 & 0.539 & 0.449 & 0.645 \\
\hline & $\begin{array}{l}\text { Error } \\
\text { (treatment*time) }\end{array}$ & 22.839 & 19 & 1.202 & & \\
\hline & Site & 11.739 & 2 & 5.870 & 1.150 & 0.338 \\
\hline & Error & 96.991 & 19 & 5.105 & & \\
\hline \multirow{3}{*}{$\begin{array}{l}\text { Maximum } \\
\text { PHA Edema } \\
(\%)\end{array}$} & Intercept & 217.292 & 1 & 217.292 & 765.898 & $<0.001$ \\
\hline & Site & 2.317 & 2 & 1.158 & 4.083 & $\mathbf{0 . 0 3 3}$ \\
\hline & Error & 5.390 & 19 & 0.8 & & \\
\hline
\end{tabular}

A set of ANOVAs with morphological, trace elements bioaccumulation as dependent variables and site (1,2 or 3) as a factor. A set of ANOVAs with physiological parameters as dependent variables and restraint (before and after) and site (1, 2 or 3 ) as a factor. For the PHA swelling response, a set of ANOVAs with relative edema (PHA or SAL $\%)$ as dependent variables and treatment (PHA or SAL), site (1, 2 or 3), and time (12 or 18h post-injection) as factors. Abbreviations: Type III SS: type III sums of squares; DF: degrees of freedom; MS: mean square; Ca: calcium; Cu: copper; Fe: iron; Zn: zinc; CORT: corticosterone; T: testosterone; N:L: neutrophil: lymphocyte ratio; BKA: bacterial killing ability; PHA: phytohemagglutinin; SAL: saline; Variables with $p$ significant at 0.05 are highlighted in bold. 
Table 3: Comparison of physiological, morphological and trace elements bioaccumulation among the three collection sites.

\begin{tabular}{|c|c|c|c|c|c|c|}
\hline Variables & Source & Type III SS & DF & MS & $\mathbf{F}$ & $P$ \\
\hline \multirow{5}{*}{$\mathrm{Mg}(\mathrm{mg} / \mathrm{mL})$} & Intercept & 1.363 & 1 & 1.363 & 457.640 & $<0.001$ \\
\hline & Site & 0.008 & 2 & 0.004 & 1.281 & 0.300 \\
\hline & Body mass & 0.013 & 1 & 0.013 & 4.336 & 0.050 \\
\hline & Site $*$ Body mass & 0.008 & 2 & 0.004 & 1.268 & 0.303 \\
\hline & Error & 0.060 & 20 & 0.003 & & \\
\hline \multirow{5}{*}{$\begin{array}{c}\text { Relative } \\
\text { Liver Mass } \\
(\%)\end{array}$} & Intercept & 161.558 & 1 & 161.558 & 5113.080 & $<0.001$ \\
\hline & Site & 0.226 & 2 & 0.113 & 3.573 & 0.047 \\
\hline & $\mathrm{C} 1$ & 0.525 & 1 & 0.525 & 16.604 & 0.001 \\
\hline & Site $* \mathrm{C} 1$ & 0.121 & 2 & 0.061 & 1.917 & 0.173 \\
\hline & Error & 0.632 & 20 & 0.032 & & \\
\hline \multirow{5}{*}{$\begin{array}{l}\text { Baseline E } \\
\text { (ng/mL) }\end{array}$} & Intercept & 2.669 & 1 & 2.669 & 20.427 & 0.006 \\
\hline & Site & 0.859 & 1 & 0.859 & 6.497 & 0.051 \\
\hline & Body mass & 2.728 & 1 & 2.728 & 20.643 & 0.006 \\
\hline & Site $*$ Body mass & 0.940 & 1 & 0.940 & 7.111 & 0.045 \\
\hline & Error & 0.661 & 5 & 0.661 & & \\
\hline
\end{tabular}

A set of ANCOVAs with Mg concentration, relative liver mass and baseline estradiol as dependent variables, site (1, 2 or 3$)$ as a factor and body mass or C1 as a covariate. Abbreviations: Type III SS: type III sums of squares; DF: degrees of freedom; MS: mean square; Mg: Magnesium; C1: PCA component 1 score; E: estradiol. Variables with $p$ significant at 0.05 are highlighted in bold. 


\title{
SUPPLEMENTARY MATERIALS
}

\section{Journal: Ecotoxicology and Environmental Safety \\ Negative influence of trace elements on steroid hormones, immunity and organ mass in toads}

\author{
Ronyelle V. Teixeira ${ }^{1 *}$, Stefanny C. M. Titon ${ }^{1,2}$, Braz Titon $\mathrm{Jr}^{3}$, Marcelo L. M. Pompêo ${ }^{4}$, \\ Fernando R. Gomes ${ }^{1}$ and Vania R. Assis ${ }^{1}$ \\ ${ }^{1}$ Laboratory of Behavior and Evolutionary Physiology, Department of Physiology, \\ Institute of Biosciences, University of São Paulo, São Paulo, Brazil. \\ ${ }^{2}$ Laboratory of Disease \& Drug-Associated Receptors Knowledge, Department of \\ Physiology, Institute of Biosciences, University of São Paulo, São Paulo, Brazil. \\ ${ }^{3}$ Laboratory of Ecophysiology and Evolutionary Physiology, Department of Physiology, \\ Institute of Biosciences, University of São Paulo, São Paulo, Brazil. \\ ${ }^{4}$ Laboratory of Limnology, Department of Ecology, Institute of Biosciences, University \\ of São Paulo, São Paulo, Brazil.
}

*Corresponding author: Ronyelle Vasconcelos-Teixeira.

ronyellevasconcelos@gmail.com

Address: Laboratório de Comportamento e Fisiologia Evolutiva. lab. 206.

Departamento de Fisiologia. Instituto de Biociências. Universidade de São Paulo.

Rua do Matão. Tr. 14. N. 101. São Paulo 05508-900. Brazil.

\section{This file includes:}

Figures $\mathrm{S} 1$ and $\mathrm{S} 2$

Tables S1 to S6 


\section{Parallelism test}

The parallelism test was done according to the methods in Assis et al. (2017), including baseline (field) and post-restraint (1h after restraint) plasma samples. Pooled samples were extracted, resuspended in ELISA buffer according to the manufacturer instructions. Pooled extracted plasma samples and the top standard (standard of the highest concentration of the kit) were serially diluted (neat, 1:2, 1:4, 1:8, 1:16, 1:31, 1:64, $1: 128,1: 256)$ and subsequentially assayed in the plate. The standard and the samples curves were plotted on the same XY axes, and the $50 \%$ of the binding point was considered indicative of the best dilution factor to run samples from that protocol (baseline or post-restraint). The standard and sample curves were all parallel, not crossing each other (Figure S3), corroborating the functionality of CORT (Figure S3A), T (Figure S3B) and E (Figure S3C) assays for R. diptycha.

\section{References}

Assis, V.R., Titon, S.C.M., Queiroz-Hazarbassanov, N.G.T., Massoco, C. de O., Gomes, F.R., 2017. Corticosterone transdermal application in toads ( Rhinella icterica ): Effects on cellular and humoral immunity and steroid plasma levels. J. Exp. Zool. Part A Ecol. Integr. Physiol. 327, 200-213. https://doi.org/10.1002/jez.2093 


\section{Plasma Corticosterone Level}
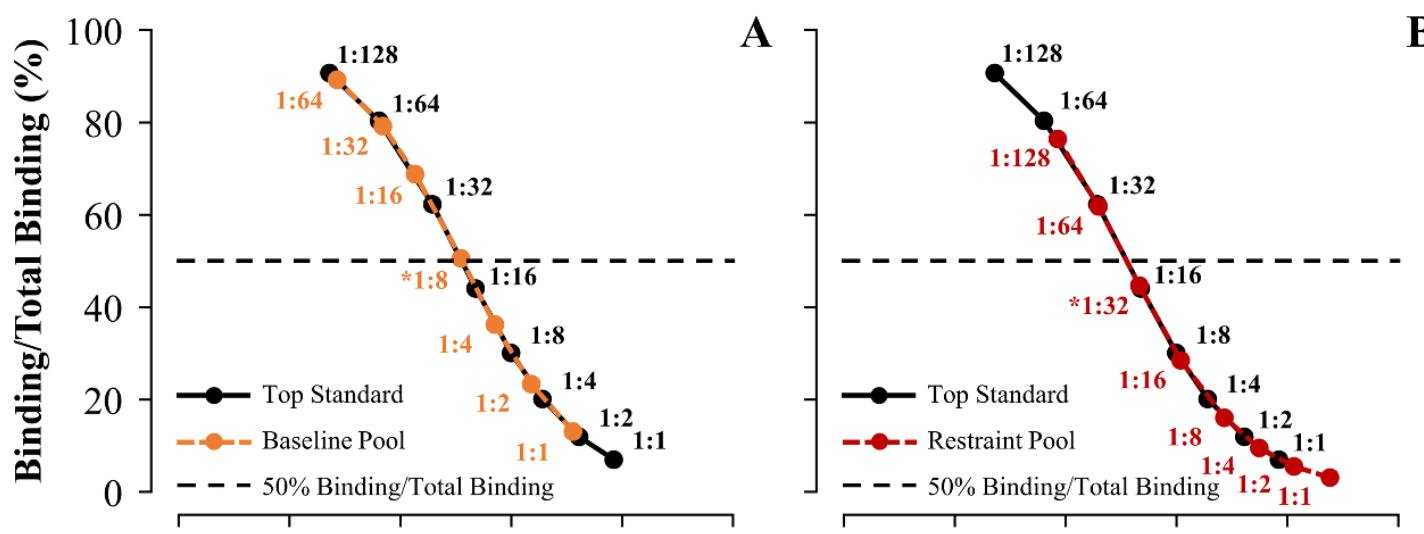

B

Plasma Testosterone Level
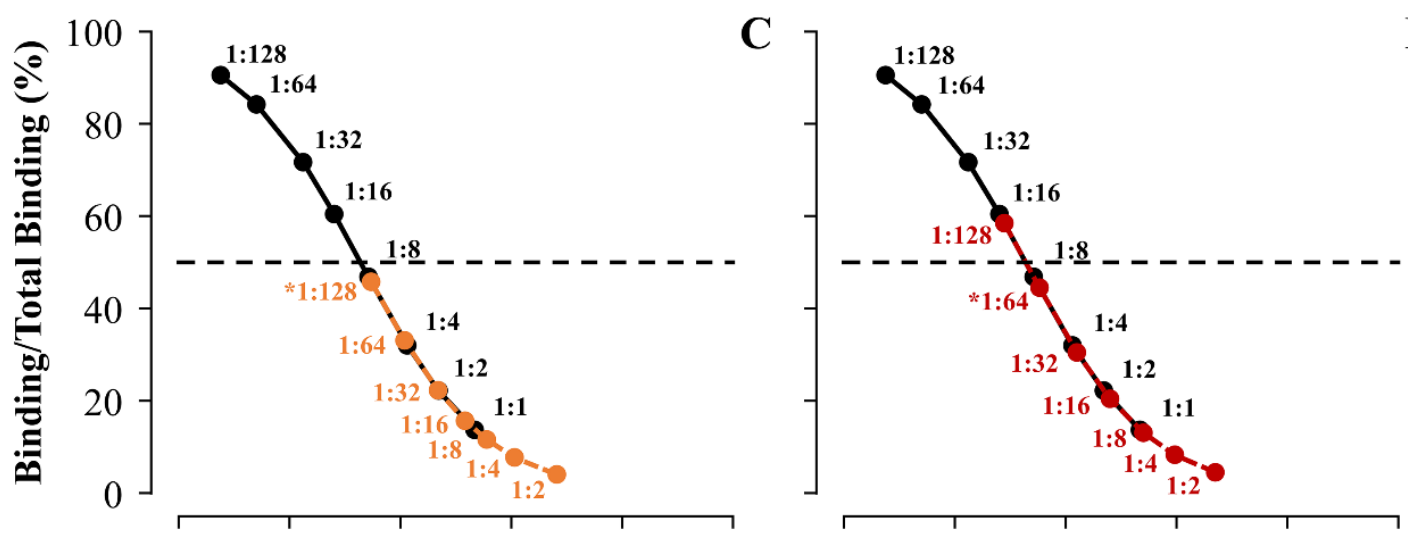

D

Plasma Estradiol Level
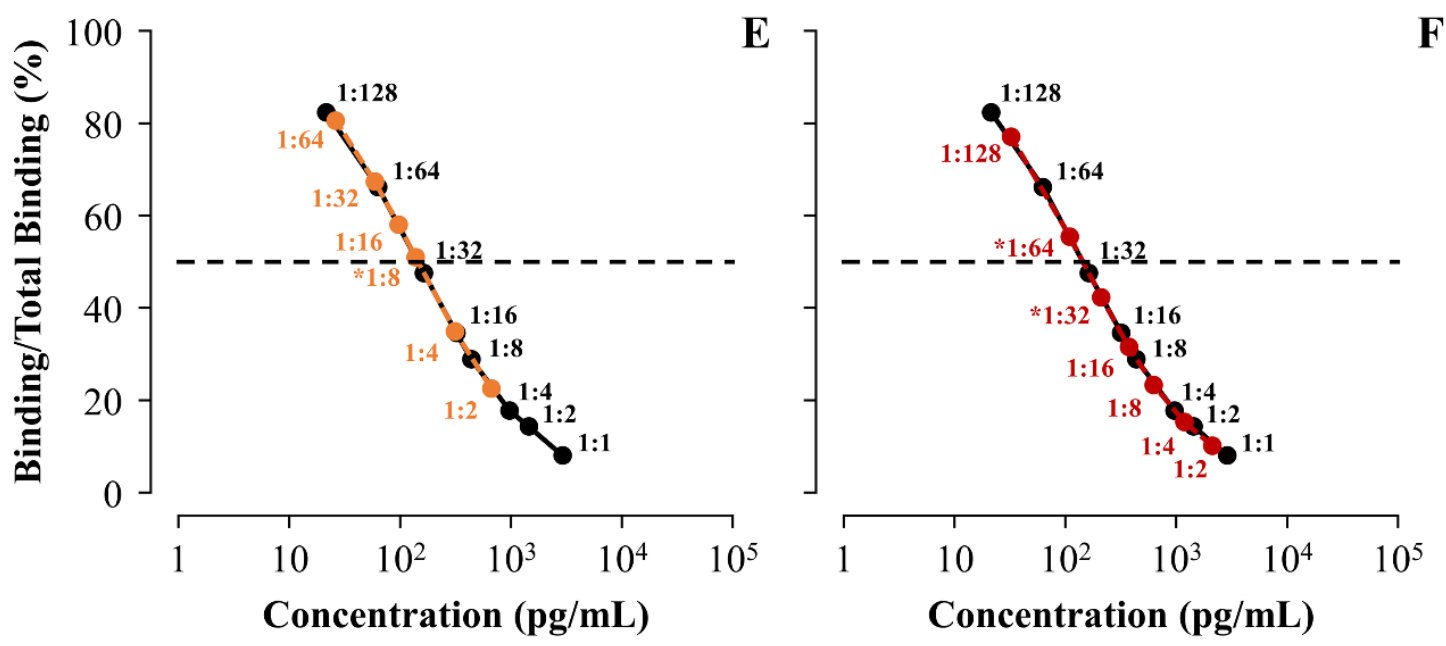

Figure S1: Binding displacement curves of serially diluted Rhinella diptycha plasma against the standards used in the enzyme immunoassays of corticosterone, testosterone, and estradiol. The y-axis shows the \% hormone bound/total binding measured at $412 \mathrm{~nm}$. Fifty percent binding point is denoted using a black dashed line, which determined the best dilution factors for the extracted plasma samples. Displacement curve of pooled plasma collected in the field (A) and $1 \mathrm{~h}$ after restraint (B) against corticosterone standard. Displacement curve of pooled plasma collected in the field (C) and $1 \mathrm{~h}$ after restraint (D) against testosterone standard. Displacement curve of pooled plasma collected in the field (E) and $1 \mathrm{~h}$ after restraint $(\mathrm{F})$ against estradiol standard. The asterisk $(*)$ represents the best dilution factors found for each hormone under each specific situation. 


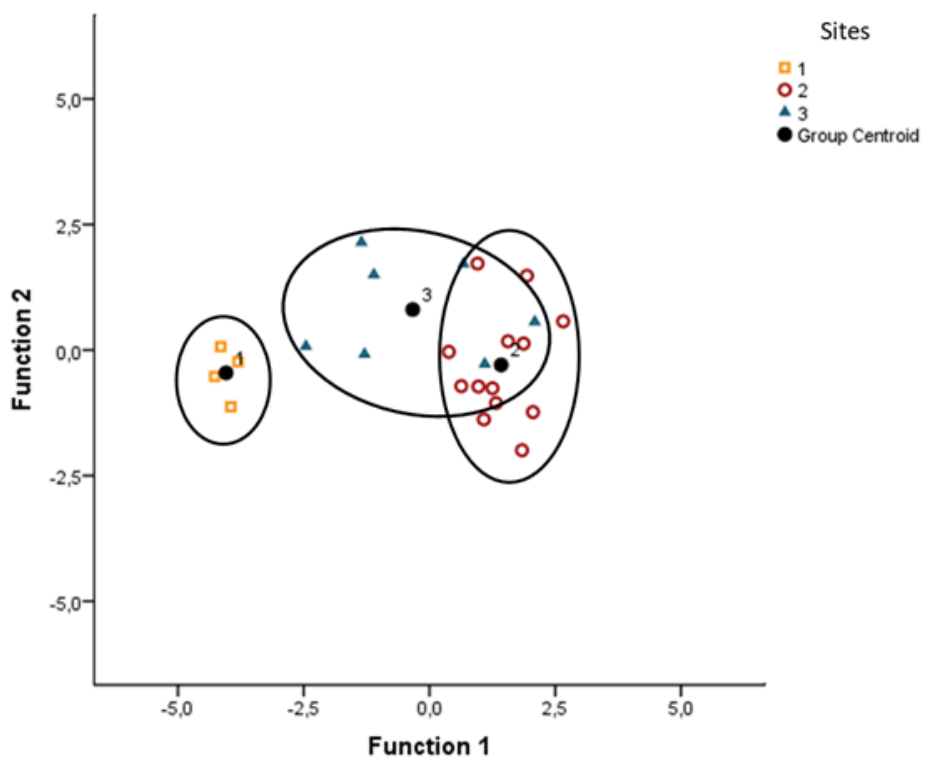

Figure S2: Linear Discriminant Analyses (LDA) for multiple groups with the trace elements detected at the liver of Rhinella diptycha. Function 1 discriminate $93.4 \%$ of the data (grouping Ca) and Function 2 discriminate $6.6 \%$ of the data (inversely grouping $\mathrm{Zn}$ with $\mathrm{Cu}, \mathrm{Fe}$ and $\mathrm{Mg}$ ). The yellow squares are the samples of site 1 (Governador Valadares (MG): 29km away from the Doce River); the red circles represent the samples of site 2 (Linhares (ES): Doce River banks); and the blue triangles are the samples of site 3 (Linhares (ES): $17 \mathrm{~km}$ away from the Doce River). The black circles are the centroids, which represents the mean of discriminant functions in each group. 
Table S1: Descriptive table of the morphological variables and trace elements in the liver of Rhinella diptycha individuals.

\begin{tabular}{|c|c|c|c|c|c|}
\hline Variables & Site & $\mathbf{N}$ & Minimum & Maximum & Mean \pm SD \\
\hline \multirow{3}{*}{ Body Mass (g) } & 1 & 9 & 58.95 & 457.35 & $198.23 \pm 159.32$ \\
\hline & 2 & 12 & 55.38 & 406.31 & $247.62 \pm 114.72$ \\
\hline & 3 & 8 & 138.85 & 374.77 & $218.15 \pm 71.98$ \\
\hline \multirow{3}{*}{ SVL (mm) } & 1 & 9 & 92.05 & 171.30 & $121.79 \pm 32.39$ \\
\hline & 2 & 12 & 90.73 & 167.74 & $138.75 \pm 25.88$ \\
\hline & 3 & 8 & 120.53 & 156 & $133.91 \pm 11.69$ \\
\hline \multirow{3}{*}{$\begin{array}{c}\text { Relative Kidneys } \\
\text { Mass (\%) }\end{array}$} & 1 & 6 & 4.51 & 6.73 & $5.57 \pm 0.97$ \\
\hline & 2 & 11 & 4.22 & 8.21 & $6.42 \pm 1.39$ \\
\hline & 3 & 9 & 3.64 & 5.82 & $4.64 \pm 0.84$ \\
\hline \multirow{3}{*}{$\begin{array}{l}\text { Relative Liver } \\
\text { Mass }(\%)\end{array}$} & 1 & 6 & 19.57 & 36.28 & $30.01 \pm 6.79$ \\
\hline & 2 & 12 & 23.20 & 43.40 & $34.48 \pm 6.59$ \\
\hline & 3 & 8 & 20.22 & 48.79 & $32.21 \pm 9.69$ \\
\hline \multirow{3}{*}{$\begin{array}{c}\text { Relative Spleen } \\
\text { Mass }(\%)\end{array}$} & 1 & 6 & 0.23 & 0.55 & $0.37 \pm 0.12$ \\
\hline & 2 & 12 & 0.25 & 0.71 & $0.44 \pm 0.15$ \\
\hline & 3 & 8 & 0.37 & 1.03 & $0.66 \pm 0.20$ \\
\hline \multirow{3}{*}{$\begin{array}{c}\text { Ca concentration } \\
(\mathrm{mg} / \mathrm{mL})\end{array}$} & 1 & 6 & 86.90 & 128.88 & $109.86 \pm 17.19$ \\
\hline & 2 & 13 & 187.76 & 329.93 & $238.00 \pm 42.18$ \\
\hline & 3 & 8 & 110.11 & 313.30 & $175.05 \pm 66.88$ \\
\hline \multirow{3}{*}{$\begin{array}{l}\mathrm{Cu} \text { concentration } \\
(\mathrm{mg} / \mathrm{mL})\end{array}$} & 1 & 4 & 90.02 & 282.38 & $154.33 \pm 86.92$ \\
\hline & 2 & 7 & 76.32 & 307.69 & $169.61 \pm 85.19$ \\
\hline & 3 & 6 & 60.23 & 379.22 & $162.09 \pm 127.68$ \\
\hline \multirow{3}{*}{$\begin{array}{l}\text { Fe concentration } \\
(\mathrm{mg} / \mathrm{mL})\end{array}$} & 1 & 7 & 150.36 & 1063.04 & $359.47 \pm 318.88$ \\
\hline & 2 & 13 & 86.38 & 723.92 & $277.45 \pm 185.09$ \\
\hline & 3 & 9 & 109.52 & 434.59 & $301.29 \pm 124.85$ \\
\hline \multirow{3}{*}{$\begin{array}{l}\text { Mg concentration } \\
(\mathrm{mg} / \mathrm{mL})\end{array}$} & 1 & 6 & 402.42 & 601.57 & $505.29 \pm 78.05$ \\
\hline & 2 & 12 & 388.15 & 547.62 & $473.12 \pm 48.04$ \\
\hline & 3 & 9 & 352.42 & 434.59 & $471.15 \pm 79.15$ \\
\hline \multirow{3}{*}{$\begin{array}{c}\text { Zn concentration } \\
(\mathrm{mg} / \mathrm{mL})\end{array}$} & 1 & 6 & 39.49 & 56.94 & $50.51 \pm 6.92$ \\
\hline & 2 & 8 & 56.32 & 73.39 & $64.11 \pm 6.00$ \\
\hline & 3 & 3 & 57.67 & 91.05 & $70.83 \pm 17.78$ \\
\hline
\end{tabular}

Data without transformation. Abbreviations: SVL: snout-vent length; Ca: calcium; Cu: copper; Fe: iron; Mg: magnesium; Zn: zinc; N: number of individuals used at the statistic tests; SD: standard deviation. Collection sites: 1: Governador Valadares (MG) - 29km away from the Doce River; 2: Linhares (ES) Doce Riverbanks; and 3: Linhares (ES) - 17km away from the Doce River. 
Table S2: Standard canonical discriminant function coefficients for trace elements in Rhinella diptycha livers and their structure matrix.

\begin{tabular}{c|rrrr}
\hline \multirow{2}{*}{ Variable } & \multicolumn{2}{|c}{ Function 1 } & \multicolumn{2}{c}{ Function 2 } \\
& Coefficient & Structure Matrix & Coefficient & Structure Matrix \\
\hline $\mathrm{Ca}$ & 1.276 & $0.634^{*}$ & -0.033 & -0.207 \\
$\mathrm{Cu}$ & 0.474 & 0.100 & 0.275 & $0.467^{*}$ \\
$\mathrm{Fe}$ & 0.442 & -0.023 & 0.372 & $0.271^{*}$ \\
$\mathrm{Mg}$ & -0.849 & -0.146 & 0.788 & $0.256^{*}$ \\
$\mathrm{Zn}$ & -0.277 & -0.105 & -1.116 & $-0.504^{*}$ \\
\hline
\end{tabular}

Asterisk (*) Represents the largest absolute correlation between each variable and their respective discriminant function. Abbreviations: Ca: calcium; Cu: copper; Fe: iron; Mg: magnesium; Zn: zinc. 
Table S3: Group membership classification results (discriminant analysis) of Rhinella diptycha in the three collection sites.

\begin{tabular}{|c|c|c|c|c|c|c|}
\hline & & \multirow[t]{2}{*}{ Sites } & \multicolumn{3}{|c|}{ Predicted Group Membership } & \multirow[t]{2}{*}{ Total } \\
\hline & & & 1 & 2 & 3 & \\
\hline \multirow{6}{*}{ Original } & \multirow{3}{*}{ Count } & 1 & 4 & 0 & 0 & 4 \\
\hline & & 2 & 0 & 12 & 1 & 13 \\
\hline & & 3 & 1 & 2 & 4 & 7 \\
\hline & \multirow{3}{*}{$\%$} & 1 & 100 & 0 & 0 & 100 \\
\hline & & 2 & 0 & 92.3 & 7.7 & 100 \\
\hline & & 3 & 14.3 & 28.6 & 57.1 & 100 \\
\hline \multirow{6}{*}{ Cross-validated } & \multirow{3}{*}{ Count } & 1 & 4 & 0 & 0 & 4 \\
\hline & & 2 & 0 & 11 & 2 & 13 \\
\hline & & 3 & 1 & 2 & 4 & 7 \\
\hline & \multirow{3}{*}{$\%$} & 1 & 100 & 0 & 0 & 100 \\
\hline & & 2 & 0 & 84.6 & 15.4 & 100 \\
\hline & & 3 & 14.3 & 28.6 & 57.1 & 100 \\
\hline
\end{tabular}

$83.3 \%$ of original grouped cases were correctly classified. The cross validation is done only for those cases in the analysis. In cross validation, each case is classified by the functions derived from all cases other than that case. Which represents, $79.2 \%$ of cross-validated grouped cases were correctly classified. The numbers highlighted in bold are the percentage of individuals properly grouped at their collection site. Collection sites: 1: Governador Valadares (MG) - 29km away from the Doce River; 2: Linhares (ES) - Doce Riverbanks; and 3: Linhares (ES) - 17km away from the Doce River. 
Table S4: Components extracted of a Principal component analysis (PCA) with trace elements presented at Rhinella diptycha livers.

\begin{tabular}{c|rr}
\hline Variables & C1 & C2 \\
\hline $\mathrm{Ca}$ & 0.632 & -0.333 \\
$\mathrm{Cu}$ & -0.134 & $\mathbf{0 . 8 4 8}$ \\
$\mathrm{Fe}$ & 0.231 & $\mathbf{0 . 5 2 2}$ \\
$\mathrm{Mg}$ & $\mathbf{0 . 8 1 6}$ & 0.176 \\
$\mathrm{Zn}$ & $\mathbf{0 . 8 3 3}$ & 0.168 \\
\% Total Variance & 36.618 & 23.244 \\
\hline
\end{tabular}

The variables grouped in each component are highlighted in bold. The total amount of variance explained by these two principal components is 59.86\%. Abbreviations: Ca: calcium; Cu: copper; Fe: iron; Mg: magnesium; Zn: zinc. 
Table S5: Descriptive table of hormonal variables of Rhinella diptycha individuals.

\begin{tabular}{|c|c|c|c|c|c|}
\hline Variables & Site & $\mathbf{N}$ & Minimum & Maximum & Mean \pm SD \\
\hline \multirow{3}{*}{$\begin{array}{l}\text { CORT Baseline } \\
\quad(\mathrm{ng} / \mathrm{mL})\end{array}$} & 1 & 8 & 0.71 & 30.60 & $4.70 \pm 9.72$ \\
\hline & 2 & 12 & 0.63 & 22.64 & $4.72 \pm 5.92$ \\
\hline & 3 & 8 & 0.69 & 3.81 & $2.08 \pm 0.90$ \\
\hline \multirow{3}{*}{$\begin{array}{l}\text { CORT Post- } \\
\text { restraint }(\mathrm{ng} / \mathrm{mL})\end{array}$} & 1 & 8 & 3.24 & 55.25 & $30.52 \pm 13.58$ \\
\hline & 2 & 12 & 7.83 & 79.55 & $35.58 \pm 20.87$ \\
\hline & 3 & 8 & 22.32 & 41.80 & $31.13 \pm 7.71$ \\
\hline \multirow{3}{*}{$\begin{array}{l}\text { T Baseline } \\
(\mathrm{ng} / \mathrm{mL})\end{array}$} & 1 & 8 & 0.31 & 5.73 & $1.57 \pm 1.79$ \\
\hline & 2 & 6 & 1.15 & 22.98 & $5.81 \pm 8.46$ \\
\hline & 3 & 5 & 1.12 & 7.53 & $3.31 \pm 2.60$ \\
\hline \multirow{3}{*}{$\begin{array}{l}\text { T Post-restraint } \\
\text { (ng/mL) }\end{array}$} & 1 & 8 & 0.19 & 1.90 & $0.94 \pm 0.61$ \\
\hline & 2 & 6 & 1.22 & 13.07 & $4.12 \pm 4.47$ \\
\hline & 3 & 5 & 1.36 & 7.53 & $3.04 \pm 1.67$ \\
\hline \multirow{2}{*}{$\begin{array}{l}\text { E Baseline } \\
(\mathrm{ng} / \mathrm{mL})\end{array}$} & 2 & 6 & 0.07 & 6.29 & $1.57 \pm 2.35$ \\
\hline & 3 & 4 & 0.54 & 12.68 & $3.82 \pm 5.92$ \\
\hline \multirow{2}{*}{$\begin{array}{l}\text { E Post-restraint } \\
(\mathrm{ng} / \mathrm{mL})\end{array}$} & 2 & 6 & 0.16 & 6.88 & $1.80 \pm 2.54$ \\
\hline & 3 & 4 & 0.63 & 9.53 & $3.22 \pm 4.24$ \\
\hline
\end{tabular}

Data without transformation. Abbreviations: CORT: corticosterone; T: testosterone; E: estradiol; SD: standard deviation. Collection sites: 1: Governador Valadares (MG) - 29km away from the Doce River; 2: Linhares (ES) - Doce Riverbanks; and 3: Linhares (ES) - 17km away from the Doce River. 
Table S6: Descriptive table of immunological variables of Rhinella diptycha individuals.

\begin{tabular}{|c|c|c|c|c|c|}
\hline Variables & Site & $\mathbf{N}$ & Minimum & Maximum & Mean \pm SD \\
\hline \multirow{3}{*}{ N:L Baseline } & 1 & 10 & 0.10 & 0.42 & $0.18 \pm 0.09$ \\
\hline & 2 & 12 & 0.14 & 0.48 & $0.24 \pm 0.12$ \\
\hline & 3 & 9 & 0.08 & 0.48 & $0.21 \pm 0.12$ \\
\hline \multirow{3}{*}{$\begin{array}{l}\text { N:L Post- } \\
\text { restraint }\end{array}$} & 1 & 10 & 0.04 & 0.52 & $0.24 \pm 0.12$ \\
\hline & 2 & 12 & 0.04 & 0.53 & $0.26 \pm 0.15$ \\
\hline & 3 & 9 & 0.17 & 0.45 & $0.32 \pm 0.10$ \\
\hline \multirow{3}{*}{$\begin{array}{c}\text { BKA Baseline } \\
(\%)\end{array}$} & 1 & 10 & 0.57 & 0.75 & $0.66 \pm 0.05$ \\
\hline & 2 & 12 & 0.56 & 0.71 & $0.65 \pm 0.06$ \\
\hline & 3 & 9 & 0.58 & 0.70 & $0.64 \pm 0.04$ \\
\hline \multirow{3}{*}{$\begin{array}{l}\text { BKA Post- } \\
\text { restraint }(\%)\end{array}$} & 1 & 10 & 0.44 & 0.77 & $0.61 \pm 0.11$ \\
\hline & 2 & 12 & 0.41 & 0.73 & $0.59 \pm 0.12$ \\
\hline & 3 & 9 & 0.53 & 0.67 & $0.59 \pm 0.06$ \\
\hline \multirow{3}{*}{ SAL $12-0(\%)$} & 1 & 7 & -4.19 & 21.57 & $6.75 \pm 11.08$ \\
\hline & 2 & 9 & -15.79 & 16.73 & $-0.42 \pm 9.94$ \\
\hline & 3 & 6 & -9.96 & 24.78 & $6.10 \pm 14.05$ \\
\hline \multirow{3}{*}{ SAL $18-0(\%)$} & 1 & 7 & -6.49 & 17.30 & $1.42 \pm 7.99$ \\
\hline & 2 & 9 & -17.58 & 5.52 & $-6.13 \pm 2.24$ \\
\hline & 3 & 6 & -16.93 & 8.88 & $-0.87 \pm 11.15$ \\
\hline \multirow{3}{*}{ PHA $12-0(\%)$} & 1 & 7 & -6.29 & 49.06 & $22.30 \pm 18.39$ \\
\hline & 2 & 9 & 7.82 & 47.45 & $26.66 \pm 13.09$ \\
\hline & 3 & 6 & 27.30 & 89.03 & $52.99 \pm 26.18$ \\
\hline \multirow{3}{*}{ PHA $18-0(\%)$} & 1 & 7 & 11.07 & 35.57 & $20.23 \pm 8.39$ \\
\hline & 2 & 9 & -6.55 & 53.60 & $14.13 \pm 17.73$ \\
\hline & 3 & 6 & 4.47 & 89.03 & $26.40 \pm 21.88$ \\
\hline \multirow{3}{*}{$\begin{array}{l}\text { PHA Maximum } \\
\text { swelling post- } \\
\text { injection }(\%)\end{array}$} & 1 & 7 & 13.22 & 49.06 & $27.39 \pm 12.36$ \\
\hline & 2 & 9 & 8.81 & 53.60 & $27.45 \pm 14.25$ \\
\hline & 3 & 6 & 27.30 & 89.03 & $52.99 \pm 26.18$ \\
\hline
\end{tabular}

Data without transformation. Abbreviations: N:L: neutrophil: lymphocyte ratio; BKA: bacterial killing ability; SAL: saline; PHA: phytohemagglutinin; 12-0: leg thickness 12 hours post-injection minus hour 0 (measurement prior to injection); 18-0: leg thickness 18 hours post-injection minus hour 0 (measurement prior to injection);.SD: standard deviation. Collection sites: 1: Governador Valadares (MG) - 29km away from the Doce River; 2: Linhares (ES) - Doce Riverbanks; and 3: Linhares (ES) - 17km away from the Doce River. 


\section{CONSIDERAÇÕES FINAIS}

De forma geral, todos os pontos de coleta apresentaram algum grau de contaminação, tanto na água quando no sedimento, provavelmente por conta das diversas atividades de mineração presentes no estado de Minas Gerais. Sabe-se que a contaminação por metais, incluindo elementos traço, pode afetar a fisiologia (ex.: interferindo em vias hormonais e metabólicas) e morfologia (ex.: aumento de órgãos e malformação) dos animais vivendo sob estas condições. Este estudo, foi conduzido em 3 locais diferentes, que apresentaram diferentes níveis de contaminação: o ponto 2 (Linhares/ES - as margens do Rio Doce) foi o mais contaminado; o ponto 1 (Governador Valadares/MG - $29 \mathrm{~km}$ distante do Rio Doce) apresentou níveis de contaminação intermediária; e o ponto 3 (Linhares/ES - 17 km distante do Rio Doce) foi o ponto com menores níveis de contaminação. Os animais do ponto menos contaminado (ponto 3) foram os mais responsivos a um estressor agudo (restrição de movimentos por $1 \mathrm{~h}$ ), apresentando uma maior relação $\mathrm{N}: \mathrm{L}$, medida normalmente associada com situações estressantes. Além disso, esses sapos apresentaram maior edema máximo após a injeção de um mitógeno, a fitohemaglutinina, demonstrando que eles também foram mais responsivos a um desafio imunológico. Os sapos desta área menos contaminada também apresentaram maiores baços, principal órgão relacionado com a resposta imune, e menores rins, órgão relacionado com a depuração de substâncias. Desta forma, nossos resultados mostram que à medida que a contaminação por elementos traço aumenta no ambiente, também aumenta a probabilidade de os animais sofrerem imunossupressão, bem como a ineficiência em montar uma resposta a um estressor agudo. Estudos utilizando mais parâmetros relacionados com imunidade (tais como análise de citocinas pró-inflamatórias, vias imunológicas, ensaios de fagocitose com as células imunes) e resposta a estresse (tais como expressão gênica de receptores de corticosterona) são 
necessários para melhor entender como os indivíduos se comportam frente a contaminação presente nas áreas de Minas Gerais e Espírito Santo, que possuem diversos polos de mineração. Estudos que quantifiquem metais pesados como arsênio e mercúrio, para verificar o acúmulo destes metais no meio ambiente e tecidos, bem como correlações com os parâmetros fisiológicos e morfológicos dos animais, também são essenciais para melhor compreender como a poluição influencia a saúde do ambiente e dos animais que ali vivem. 


\section{ANEXOS}

- Anexo 1:

\section{TSJUniversidade de siso Pavio \\ คำ Instituto Biociências}

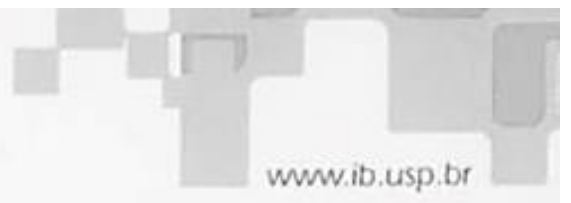

\section{CERTIFICADO}

Certificamos que a proposta intitulada "Efeitos de contaminantes químicos no rio doce: como as populações de anuros estão sendo afetadas?", registrada com o ne 303/2017, sob a responsabilidade do Prof. Dr. Fernando Ribeiro Gomes e com a participaçăo das colaboradoras Ronyelle Vasconcelos Teixeira (IB/USP), Vảnia Regina de Assis (IB/USP), Stefanny Christie Monteiro Titon (IB/USP, que envolve a utilização de animais pertencentes ao filo Chordata, subfilo Vertebrata (exceto humanos), para fins de pesquisa cientifica encontra-se de acordo com os preceitos da Lei $n^{2} 11.794$, de 08 de outubro de 2008, do Decreto $n^{2} 6.899$, de 15 de julho de 2009 e com as normas editadas pelo Conselho Nacional de Controle da Experimentaçăo Animal (CONCEA), e foi aprovada pela Comissão de Ética no Uso de Animais - CEUA do Instituto de Biociências da Universidade de São Paulo, em reunião de 11 de dezembro de 2017.

Vigência da autorizaç̃̃o: 11/12/2017 a 30/08/2019

Finalidade: Pesquisa Cientifica

№ da solicitaçăo ou autorização SISBIO: 29896-1

Atividade: Captura e coleta de espécimes

Espécies/Grupos Taxonômicos: Anfibio/Rhinella schineideri (sapo-cururu ou sapo-boi), Rhinella ictérica (sapo-cururu), Hypsiboas faber (sapo-martelo)

№ de animais: 80 (M) e 40(F) Peso: 80 a $300 \mathrm{~g}$ Idade: 3 anos Total: 120 animais Locais de realização das atividades: arredores das cidades de Ipatinga e Governador Valadares - MG e Linhares - ES.

OBS.: Qualquer alteração e/ou intercorrència deverá ser comunicada a CEUA-IB.

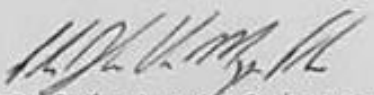

Prof. Dr. Pedro Augusto Carlos Magno Fernandes Coordenador da Comissăo de Ética no Uso de Animais 